\title{
Second Thoughts About Summary Judgment
}

\author{
Samuel Issacharoff $\dagger$ and George Loewenstein $\mathfrak{f}_{\dagger}^{\dagger}$
}

Over the past decade, docket pressures on the federal judiciary have prompted dramatic revisions in federal procedure. These revisions have sharply increased the administrative power of the federal courts to determine which claims are sufficiently meritorious to be brought to trial. The 1983 amendments to the Federal Rules of Civil Procedure granted broad managerial control to the federal judiciary to direct that all cases be subject to negotiation under the aegis of the courts and that wayward counsel be subject to court-imposed sanctions. ${ }^{1}$ Thus armed, the courts were sent off to battle against the docket pressures of a society seemingly bent on litigation for all manner of perceived ills. ${ }^{2}$

In 1986, the Supreme Court added another weapon to the arsenal designed to check the spread of litigation. In a trilogy of cases addressing the standards for presenting a claim to the ultimate trier of fact-Celotex Corp. v. Catrett, ${ }^{3}$ Anderson v. Liberty Lobby, ${ }^{4}$ and Matsushita Electric Industrial Corp. v. Zenith Radio ${ }^{5}$ - the Court significantly expanded the applicability of summary judgment under Rule 56 of the Federal Rules of Civil Procedure which denies litigants access to trial when the court determines that there is "no genuine issue as to any material fact" such as to preclude "judgment as a matter of law." These cases brought into the battle against excess litigation a weapon held

$\dagger$ Assistant Professor, University of Texas School of Law; J.D., Yale Law School, 1983.

t† Associate Professor of Economics, Department of Social and Decision Sciences, Carnegie Mellon University; Ph.D. Economics, Yale University, 1985. The authors wish to thank Troyen Brennan, Cynthia Estlund, Jack Getman, Robert Gertner, Mary Kay Kane, William Lang, Douglas Laycock, Richard Markovits, Geoffrey Miller, Jack Ratliff, Edward Sherman, Charles Silver and the participants in the University of Texas Law School Faculty Colloquium for their comments on drafts of this article.

1. A. MILLER, THE August 1983 AMENDMENTS to THE FEDERAL RULES OF CIVIL PROCEDURE: PROMOTING EFFECTIVE CASE MANAGEMENT AND LAWYER RESPONSIBILITY 2 (1983 amendments "Tepresent an integrated package" granting greater managerial discretion to federal courts).

2. See Galanter, The Day After the Litigation Explosion, 46 MD. L. REv. 3,15 n.44 (1986) (assembling statistics on litigation growth). Although Professor Galanter disputes the conclusion of America as a litigiously-oriented society, his figures nonetheless reveal that the total number of cases filed in federal courts more than doubled between 1975 and 1984. Id. See also Burger, Isn't There a Better Way?, Annual Report on the State of the Judiciary 68 A.B.A. J. 274 (1982); Hensler, Trends in Tort Litigation: Findings from the Institute for Civil Justice Research, 48 OHIO ST. L.J. 479 (1987); R. POSNER, THE FEDERAL COURTS: CRISIS AND REFORM 76-77 and App. B, Table B.2 (1985) (showing approximately $400 \%$ increase in federal civil filings from 1963 to 1983); Robel, Caseload and Judging: Judicial Adaptations to Caseload, 1990 B.Y.U. L. REV. 3, 6-12 (reporting judges' perceptions of caseload effects).
3. 477 U.S. 317 (1986).
4. 477 U.S. 242 (1986).
5. 475 U.S. 574 (1986). 
largely in reserve by the federal courts since the promulgation of the Federal Rules in 1938.

The summary judgment trilogy seems consistent with the spirit of the 1983 revisions to the Federal Rules in encouraging the judiciary to screen as well as adjudicate cases. ${ }^{6}$. Summary judgment provides a mechanism for the courts to review cases prior to trial once the parties have concluded the discovery necessary to establish the existence of material issues in dispute. ${ }^{7}$ Indeed, the current proposed revisions to the Federal Rules would create a category of "summary establishment of fact and law" under which the courts would have increased authority to decide which factual issues merit adjudication at trial. ${ }^{8}$

The expansion of summary judgment is designed to control both the volume of litigation overall and its scope in any particular case. ${ }^{9}$ However, as we argue below, the impact of altering summary judgment rules goes beyond this hopedfor screening function. Alterations of summary judgment procedures have consequences for the information balance between, and incentives operating on, both parties, and these in turn affect the entire spectrum of decisions facing litigants, from the filing of lawsuits to the choice between settling and litigating the claim through to trial. To some extent, moreover, the expansion of summary judgment is subject to the normative critiques directed against bringing institutional pressures to bear to force non-adjudicated resolution of disputes. ${ }^{10}$ This Article, however, takes as its point of departure the articulated premises of the expansion of summary judgment, primarily its claimed role in reducing litigation. Having assumed the propriety of these premises, this Article critically examines the extent to which the desired effects are likely to be realized, and at what cost.

An economic analysis of the impact of the relaxed summary judgment rules reveals the extent to which summary judgment actually limits litigation and the extent to which its additional unintended consequences may compromise its effectiveness as a tool to relieve docket pressure on the federal courts. This

6. Lambros, The Federal Rules of Civil Procedure: A New Adversarial Model for a New Era, $50 \mathrm{U}$. PITT. L. REV. 789, 795 (1989) (tying in altered Rule 56 with the 1983 amendments to Rules 7, 11, and 16).

7. See FED. R. CIV. P. 56(f) (providing for deferral of consideration of summary judgment motion until discovery is complete).

8. For an extensive discussion of the proposed modifications of Rule 56, see Carrington, Making Rules to Dispose of Manifestly Unfounded Assertions: An Exorcism of the Bogy of Non-Trans-Substantive Rules of Civil Procedure, 137 U. PA. L. REV. 2067, 2094-05 (1989).

9. See Advisory Committee Notes, Proposed Rules at 170 (this "device is especially encouraged in complex cases in which issues of fact may metastasize if the court does not take action to confine the dispute and proscribe costly overextension of discovery and trial").

10. The leading exponent of this view is Professor Owen Fiss who sees the prospect of peace between the parties achieved outside of full adjudication as risking the public loss of the explication and articulation of legal and constitutional rights. See Fiss, Against Settlement, 93 YALE L.J. 1073, 1085 (1984). See also Edwards, Alternative Dispute Resolution: Panacea or Anathema?, 99 HARv. L. REV. 668, 677-78 (1986) ("mere resolution of a dispute is not proof that the public interest has been served"); Higginbotham, The Priority of Human Rights in Court Reform, 70 F.R.D. 134, 138 (1976) (reform must be measured against societal objectives). 
analysis demonstrates that summary judgment is an effective screening measure insofar as it intercepts cases that are of marginal value to the plaintiff or those that are simply non-meritorious or frivolous. However, this desired effect is counterbalanced by two potential unanticipated consequences.

First, the eased standards for bringing summary judgment motions may have adverse consequences for the ability of the parties to settle cases where summary judgment motions have been made and denied. Given that the vast majority of cases in the federal courts settle well prior to any litigated outcome, any compromise of the settlement rate could have a negative systemic effect on federal litigation overall. Such an adverse impact would be contrary to the conventional wisdom that summary judgment should promote fair settlements by forcing an evidentiary confrontation prior to trial. ${ }^{11}$

Second, summary judgment fundamentally alters the balance of power between plaintiffs and defendants by raising both the costs and risks to plaintiffs in the pretrial phases of litigation while diminishing both for defendants. Even where summary judgment motions are not filed, the potential use of liberalized summary judgment procedures is sufficient to lower the expected value to plaintiffs of settled claims. Therefore, liberalized summary judgment inhibits the filing of otherwise meritorious suits and results in a wealth transfer from plaintiffs as a class to defendants as a class.

This article will analyze the consequences of the summary judgment trilogy from several perspectives. In the following section, we undertake a doctrinal review of the origins and purposes of the summary judgment trilogy to assess the legal underpinnings of the altered standards under Rule 56. Section II presents an economic analysis of the consequences of summary judgment on settlement rates, efficiency, and the balance of power between plaintiffs and defendants in light of its impact on the timing and magnitude of costs incurred by the parties. Section III further extends this analysis by considering the impact of extrinsic factors that may further complicate the new summary judgment balance, such as the role of repeat litigants and the strategic use of information obtained in summary judgment. In Section IV we examine various procedural alterations that could mitigate the problems identified with the posttrilogy summary judgment standard; we evaluate the predicted impact of modifications such as precluding defendants from introducing evidence that was available but not introduced at the time of the summary judgment motion, and fee shifting, where the defeat of a summary judgment motion will trigger the payment of fees and costs incurred by the nonmovant in defending against the summary judgment motion.

11. This evidentiary confrontation is thought to promote settlements by forcing both parties to tackle the scope of the factual record and to balance the realistic probabilities of success against the costs associated with further litigation. See Posner, An Economic Approach to Legal Procedure and Judicial Administration, 2 J. LEGAL STUD. 399, 417-20 (1973). 


\section{SUMMARY JUdGMENT UNDER THE TRILOGY}

Summary judgment is a relative newcomer to the Anglo-American legal scene. The origins of summary judgment can be traced to the Bills of Exchange Act of 1855 in England ${ }^{12}$ which developed a rudimentary procedure for summary judgment in a narrow category of contract cases involving liquidated claims met with only spurious defenses. ${ }^{13}$ Summary judgment was a mechanism to combat the "law's delay" 14 by allowing courts to strike "any frivolous or sham defense to the whole or to any part of the complaint." ${ }^{15}$ It provided plaintiffs with a motion somewhat akin to a post-pleading default judgment. As expressed by the Supreme Court, the purpose of summary judgment was "to preserve the court from frivolous defences and to defeat attempts to use formal pleading as means to delay the recovery of just demands."16

Although an increasing number of state courts used variants of summary judgment by the early part of this century, ${ }^{17}$ it remained an exceptional practice. Prior to the adoption of the Federal Rules of Civil Procedure in 1938, the Supreme Court had only once confronted the constitutional issues raised by summary judgment and had upheld the narrow use of the procedure to reject frivolous defenses. ${ }^{18}$ The Federal Rules of Civil Procedure, first promulgated in 1938, extended the applicability of this device to all cases, including those arising in equity, and to all parties. ${ }^{19}$ The Federal Rules made summary judgment available, at least in principle, as a broad-scale tool for the entry of a final decree on the merits of all claims before the federal courts. This expansion

12. The Summary Procedure on Bills of Exchange Act, 1855, 18 \& 19 Vict. c. 67 (1855). See also Louis, Federal Summary Judgment Doctrine: A Critical Analysis, 83 Y ALE L.J. 745, 745 (1974); Clark \& Samenow, The Summary Judgment, 38 YALE L.J. 423, 424 (1929).

13. See generally 10 C. WRIGHT, A. MILLER \& M. KANE, FEDERAL PRACTICE \& PROCEdURE, § 2711 (2d ed. 1983).

14. See Clark \& Samenow, supra note 12 , at 423.

15. An Act to Regulate the Practice of Courts of Law, ch. 231, 1912 N.J. Laws 377, 380; 2 N.J. Comp. Stat. (Supp. 1915) $\S \S 15,16$.

16. Fidelity \& Deposit Co. v. United States, 187 U.S. 315, 320 (1902). The Court in Fidelity relied heavily on the unreported opinion of the Court in Smoot v. Rittenhouse (Jan. 10, 1876), which upheld the use of summary judgment in liquidated contract claims as against a constitutional challenge that it denied defendant the right to trial by jury.

17. See Clark \& Samenow, supra note 12 , at $440-470$ (giving state by state descriptions of summary judgment procedures); Millar, Three American Ventures in Summary Civil Procedure, 38 YALE L.J. 193 (1928) (review of summary judgment in three Southern states).

18. Fidelity \& Deposit Co. v. United States, 187 U.S. at 320 . In addition, the Supreme Court had affirmed the use of summary judgment against sureties on appeal bonds and on appeal bonds themselves. Pease v. Rathbun-Jones Eng'g Co., 243 U.S. 273, 279 (1917); see also id. at 278 nn.1 \& 2 (listing cases).

19. 10 C. WRIGHT, A. MILLER \& M. KANE, supra note $13, \S 2711$. The Federal Rules Committee relied upon the 1933 extension of summary judgment in New York State procedure to allow for judgment for defendants as well as plaintiffs. Report of the Commission on Administration of Justice in New York Srate 287 (1934). The New York State Commission encouraged the broad use of summary judgment for all causes of action, as well as all parties. Id. 
represented a significant alteration of American jurisprudence, which had guaranteed access to trial by jury as a right of constitutional magnitude. ${ }^{20}$

From its inception, federal judges treated summary judgment warily, perceiving it as threatening a denial of such fundamental guarantees as the right to confront witnesses, the right of the jury to make inferences and determinations of credibility, and the right to have one's cause advocated by counsel before a jury. ${ }^{21}$ For example, in 1962 the Supreme Court discouraged the use of summary judgment in antitrust litigation, stating "[t]rial by affidavit is no substitute for trial by jury which so long has been the hallmark of 'even handed justice. " "22 Even the reporter for the original Federal Rules Committee, Judge Charles Clark, was unable to implement the broad use of summary judgment in his home forum, the Second Circuit. ${ }^{23}$ Until the Supreme Court decided the 1986 summary judgment trilogy, the Second Circuit required denial of summary judgment whenever the "slightest doubt" existed as to whether the nonmovant might persuade a jury of the merits of her case. ${ }^{24}$ The "slightest doubt" standard earned the Second Circuit a widespread reputation for hostility to summary judgment motions. ${ }^{25}$

Summary judgment fared little better in other courts. In the Third Circuit, to take another example, summary judgment was denied as a matter of law when the motion was contrary to averments that were "well-pleaded," that is, not even a factual matter of record. ${ }^{26}$ Although the 1963 Amendment to Rule

20. U.S. CONST. amend. VII. The strongest articulation of this view occurs in Justice Black's concurrence in Adickes v. S.H. Kress \& Co., 398 U.S. 144, 176 (1970): "[Plaintiff Adickes] may have had to prove her case by impeaching the [defendant's] witnesses .... The right to confront, cross-examine and impeach adverse witnesses is one of the most fundamental rights sought to be preserved by the Seventh Amendment ...." Justice Black's reasoning was endorsed by the Supreme Court in Poller v. CBS, Inc., 368 U.S. 464 (1962), where the Court indicated that the preservation of the right to confront witnesses was of critical importance in cases where liability turns on motive or intent. Id. at 472-73. But see First Nat'l Bank of Arizona v. Cities Serv. Co., 391 U.S. 253, $298-99$ (1968) (holding that courts do not exist to provide opportunity for litigation gambles to pay off). See generally Friedenthal, Cases on Summary Judgment: Has There Been a Material Change in Standards?, 63 NOTRE DAME L. REV. 770, 771-75 (1988).

21. See, e.g., Colby v. Klune, 178 F.2d 872, 873 (2d Cir. 1949) (opinion of Judge Jerome Frank, a leading opponent of summary judgment); Arnstein v. Porter, 154 F.2d 464, $469-70$ (2d Cir. 1946) (same); cf. Comment, Summary Judgment: The Majority View Undergoes a Complete Reversal in the 1986 Supreme Court, 37 EMORY L.J. 171, 173-80 (1988) (describing debate in Second Circuit between Judge Frank and Judge Charles Clark, the reporter for the Federal Rules Committee).

22. Poller v. CBS, Inc., 368 U.S. at 473.

23. Arnstein v. Porter, 154 F.2d at 479 (Clark, J., dissenting) (accusing majority of subverting purposes of adoption of federal rules by refusing to permit broad use of summary judgment).

24. See, e.g., Dolgow v. Anderson, 438 F.2d 825, 830 (2d Cir. 1970); see also Louis, Federal Summary Judgment Doctrine: A Critical Analysis, 83 YALE L.J. 745, 760-62 (1974) (discussing Second Circuit summary judgment standard).

25. See Knight v. U.S. Fire Insurance Co., 804 F.2d 9, 12 (2d Cir. 1986), cert. denied, 480 U.S. (1987) (acknowledging prior "perception that this court is unsympathetic to such motions and frequently reverses grants of summary judgment").

26. See, e.g., Frederick Hart \& Co., Inc. v. Recordgraph Corp., 169 F.2d 580 (3d Cir. 1948). The Third Circuit view was rejected by a 1963 Amendment to the Federal Rules in the only substantive change to Rule 56 since its promulgation. In the words of the Advisory Committee Notes, "[i]t is hoped that the amendment will contribute to the more effective utilization of the salutary device of summary judgment." FED. R. CIV. P. 56 advisory committee's notes, 1963 Amendment. 
56 expressly rejected the Third Circuit view, ${ }^{27}$ Justices Black and Douglas endorsed that view, criticizing the amendment for transforming summary judgment into "a handy instrument to let judges rather than juries try laws [sic] suits and to let those judges try cases not on evidence of witnesses subjected to cross-examination but on ex parte affidavits obtained by parties."28 The oftrecounted tale of the sign posted in a New Orleans district court, "No Spitting, No Summary Judgments," 29 encapsulates the extreme version of judicial antipathy to summary judgment. Trial courts, faced with uncertain standards for summary judgment and extraordinary reversal rates in cases where judgment was granted, denied the motion whenever any doubt was present..$^{30}$ Increasingly, summary judgment became a litigation tool of the well-heeled litigant who saw in Rule 56 potential strategic value "as a discovery device; to educate the trial judge; in the hope, however faint, of quick victory; and in the expectation, frequently realized, of retarding the progress of a suit and making litigation more expensive." 31

Not surprisingly, summary judgment began to attract renewed interest from commentators as the press of litigation continued to mount on the federal judiciary. ${ }^{32}$ Particularly in light of the 1983 amendments to the Federal Rules

27. FED. R. CIV. P. 56 advisory committee's notes, 1963 Amendment.

28. 12 C. WRIGHT \& A. MILLER, FEDERAL PRACTICE AND PROCEDURE app. B (Orders of the Supreme Court of United States Regarding Civil Rules) (statement of Justices Black and Douglas opposing submission of Rules of Civil Procedure because they do not satisfy legislative requirements of bicameralism and presentment) (1973). Justices Black and Douglas added, "[m]ost trial lawyers would agree, we think, that a litigant can frequently obtain in an actual trial favorable testimony which could not have been secured by affidavits or even by depositions." Id.

29. Childress, A New Era for Summary Judgments: Recent Shifts at the Supreme Court, 6 REV. OF LITIG. 263, 264 (1987); see also Croxen v. United States Chemical Corp., 558 F. Supp. 6, 7 (N.D. Iowa 1982) (summary judgment "an extreme and treacherous remedy"). The doctrinal formulation of these aphorisms is that "summary judgment should be used sparingly in all cases, and it is only with great caution and much soul-searching that such motions will be granted." Bayou Bottling, Inc. v. Dr. Pepper Co., 543 F. Supp. 1255, 1261 (W.D. La. 1982), aff' 725 F.2d 300 (5th Cir.), cert. denied, 469 U.S. 833 (1984).

30. Louis, supra note 12, at 746. One study of disposition of summary judgment rulings on appeal found that only 51.4 percent of 215 appealed decisions were affirmed. McLauchlan, An Empirical Study of the Federal Summary Judgment Rule, 6 J. LEGAL STUD. 427, 449 (1977). See generally Note, Federal Summary Judgment: The "New" Workhorse for an Overburdened Federal Court System, 20 U.C. DAVIS L. REV. 955, 956 n.6 (1987) (citing authorities on reversal rates and perceptions of summary judgment as disfavored procedure).

31. Professional Managers, Inc. v. Fawer, Brian, Hardy \& Zatkis, 799 F.2d 218, 221-22 (5th Cir. 1986).

32. The leading academic advocate of relaxing the standards for granting summary judgment has been Professor Martin Louis. See Louis, supra note 12. Professor Louis advocates recasting the burden of production on the moving party to reflect the ultimate burden that the movant would bear at trial. Under his standard, a defendant-movant would still bear a substantial burden of going forward, although not as heavy as that of a plaintiff-movant-a position apparently similar to the views of Justice White in Celotex. See Louis, Intercepting and Discouraging Doubtful Litigation: A Golden Anniversary View of Pleading, Summary Judgment, and Rule 11 Sanctions Under the Federal Rules of Civil Procedure, 67 N.C. L. REV. 1023 (1989). Other commentators endorsing a modification of the burden of production on a summary judgment movant to reflect that party's ultimate burden at trial include Bogart, Currie and Pielemeier. See Bogart, Summary Judgment: A Comparative and Critical Analysis, 19 OSGOODE HALL L.J. 552, 594-95 (1981); Currie, Thoughts on Directed Verdicts and Summary Judgments, 45 U. CHI. L. REV. 72, 78 (1977); Pielemeier, Summary Judgment in Minnesota: A Search for Patterns, 7 WM. MTCHELL L. REV. 147, 158 (1981). Professor Currie further advocates removing virtually all barriers to the motion for summary 
granting the district courts unprecedented powers in the management of cases, the restrictive view of summary judgment seemed decisively out of step with the attempt to streamline the civil dockets by modifying civil procedure. In addition, the expansion of summary judgment corresponded to the infusion of economic analyses of incentive structures in civil procedure. Since, according to this view, obstacles to settlement grow primarily out of imperfect information about the relative merits of each side's case, ${ }^{33}$ and since summary judgment provides for a final round of pretrial exchange of information, an expansion of summary judgment should presumably facilitate settlement.

The summary judgment trilogy fundamentally altered Rule 56 in two ways. First, these cases eased the initial burden placed on the party moving for summary judgment by permitting a summary judgment movant to prevail without having to establish fully the nonexistence of material facts in dispute. Second, the Court allowed greater district court latitude in determining the existence of issues meriting trial, thereby easing the grant of summary judgment. Together, these cases give increased prominence to summary judgment in modern litigation.

\section{A. Recasting the Movant's Burden}

Under Rule 56(e), a motion for summary judgment is to be "made and supported as provided in this rule." ${ }^{34}$ Case law prior to Celotex treated this ambiguously worded requirement in the same terms as would apply to a movant generally, that is, as a requirement that the movant carry the burden of proof on the subject of the motion. ${ }^{35}$ The leading case prior to Celotex was Adickes v. S.H. Kress \& Co., ${ }^{36}$ which involved a conspiracy claim arising out of the refusal of luncheonette service to, and subsequent arrest of, a white civil-rights worker in Hattiesburg, Mississippi. The conspiracy claim was premised on an allegation of concerted activity between a private actor (S.H. Kress) and state actors (the police who ultimately arrested Ms. Adickes for vagrancy). The record contained allegations that the arresting policeman had been in the store when service was refused, but there was no evidence presented by the plaintiff as to any conspiratorial activity other than the policeman's possible presence. Defendant then sought summary judgment on the grounds that "uncontested

judgment made by parties not bearing the ultimate burden of proof at trial. He recommends that the movant be required to bear only a limited burden of production, so that the nonmovant will be held to proving the issues of fact that remain in dispute.

33. See R. POSNER, ECONOMIC ANALYSIS OF LAW 525-26 (3d. ed. 1986); Posner, supra note 11, at 423. For a fuller discussion of the merits of this view of summary judgment, see infra text accompanying notes 143-51.

34. FED. R. CIV. P. 56(e).

35. See, e.g., Williams v. Taylor, 677 F.2d 510, 514 (5th Cir. 1982); Mustang Fuel Corp. v. Youngstown Sheet \& Tube Co., 516 F.2d 33, 36 (10th Cir. 1975); see also C. WRIGHT, HANDBOOK OF THE LAW OF FEDERAL COURTS \& 99, at 668 n.29 (4th ed. 1983).

36. 398 U.S. 144 (1970). 
facts," including the unrebutted affidavits of the store manager and several police officers, pointed against a conspiracy and that plaintiff had failed to introduce substantive evidence to support the existence of the conspiracy. The Supreme Court rejected this argument: "[T] he moving party ... ha[s] the burden of showing the absence of a genuine issue as to any material fact, and for these purposes the material it lodged must be viewed in the light most favorable to the opposing party." ${ }^{37}$ The motion for summary judgment failed, the Supreme Court held, because the affidavits of record did not foreclose a possible inference of a conspiracy by the jury from the fact that the policeman was present at the time that service was refused. Since such an inference could not be foreclosed from the "factual allegations of [Adickes'] complaint, as well as the material found in the affidavits and depositions presented by Kress . . . , [Kress] failed to carry its burden of showing the absence of any genuine issue of fact."38

The Court in Adickes did not address what evidence, short of Kress's satisfying its complete burden of proof of negating the existence of issues in dispute, might suffice to shift the burden of production to the plaintiff to establish the viability of her case. Nonetheless, Adickes was widely interpreted to require a movant for summary judgment to "foreclose the possibility" that the nonmovant might prevail at trial. ${ }^{39}$

The Supreme Court revisited the issue of the movant's burden under summary judgment in Celotex. Because the claim in Celotex turned on the alleged exposure of the plaintiff's deceased husband to asbestos products produced by Celotex Corporation, a strict application of Adickes would for all practical purposes defeat any prospect of summary judgment. Under such an application, the defendant would have to prove nonexposure at any point in the decedent's life in order to foreclose the possibility of a plaintiff's verdict at trial.

While nodding to the continued viability of Adickes, the Supreme Court in Celotex recast the burden to be shouldered by a party moving for summary judgment. Under Celotex a movant's burden of production - the quantum of evidence needed from which an inference in favor of the movant might be drawn-comports with the ultimate burden of proof the movant would have at trial. As a result, Celotex still conformed to the normal requirement that a movant bear the ultimate burden for her motion. But Celotex also refocused the

37. Id. at 157.

38. Id. at 153 .

39. Board of Educ. v. Pico, 457 U.S. 853, 875 (1982) (affirming reversal of summary judgment on grounds that defendant-movants had not foreclosed possibility that removal of books from school library was unconstitutionally motivated); Smith v. Hudson, 600 F.2d 60, 64 (6th Cir.) cert. dismissed, 444 U.S. 986 (1979) (relying on Adickes to establish that "burden of establishing the nonexistence of a material factual dispute always rests with the movant"); Rose v. Bridgeport Brass Co., 487 F.2d 804, 808 (7th Cir. 1973) (same); see also Nelken, One Step Forward, Two Steps Back: Summary Judgment After Celotex, 40 HASTINGS L.J. 53, 63-64 \& n.56 (1988). 
critical inquiry to the question of the burden of production that a movant must satisfy to shift that intermediate burden to the nonmovant to establish her right to go to trial. Instead of a uniform burden imposed upon the movant, the Court decreed that the movant's burden of production for summary judgment would depend on the movant's ultimate burden of proof at trial. ${ }^{40}$

Thus, while the issue of how the movant's burden of production is to be satisfied is not conclusively resolved, each of the three summary judgment opinions in Celotex ${ }^{41}$ represents a retreat from the Adickes standard for summary judgment with regard to the burden of production that would be required of a movant for summary judgment. Under Adickes, the movant bears the burden of proof on the motion for summary judgment and bears the full burden of production, regardless of the ultimate burden that party would bear at trial..$^{42}$ The varying Celotex standards assume the movant to bears the burden of proof for the motion, but diverge as to the burden of production required to force the plaintiff nonmovant to prove the existence of facts in dispute. For the Rehnquist plurality the burden would be that of simply "informing" the court of the absence of facts in dispute. ${ }^{43}$ For Justice White, who provides the crucial fifth vote, a mere "conclusory assertion" that no evidence supports plaintiff is insufficient to discharge the movant's burden of production. ${ }^{44}$ Justice Brennan, in dissent, offers the movant without the burden of proof at trial two options to satisfy its burden of production: either (1) introduce affirmative evidence negating an essential element of the plaintiff's claim, or (2) affirmatively demonstrate that there is no evidence in the pleadings, documents or affidavits in the record to support plaintiff's claim. ${ }^{45}$

After Celotex, the movant who does not carry the ultimate burden at trial-i.e., a defendant moving for summary judgment ${ }^{46}$ - would bear a far lesser initial burden than previously, now defined by the plurality opinion as "the initial responsibility of informing the district court of the basis for its motion . . . ."47 According to Chief Justice Rehnquist, "the burden on the moving party may be discharged by 'showing'-that is, pointing out to the

40. 477 U.S. at 324 .

41. The three opinions are by Justices Rehnquist, White and Brennan. Justice Rehnquist authored the lead opinion for himself and Justices Marshall, Powell and O'Connor. 477 U.S. at 319. Justice White concurred to provide the necessary fifth vote. Id. at 328 . Justice Brennan authored a dissent for himself, Chief Justice Burger and Justice Blackmun. Id. at 329. Justice Stevens dissented on an unrelated jurisdictional issue. Id. at 337.

42. See, e.g., $6 \mathrm{~J}$. MOORE, FEDERAL PRACTICE $§ 56.15[3]$ (2d. ed. 1988) (supporting this as traditional view).

43. 477 U.S. at 323.

44. 477 U.S. at 328.

45. 477 U.S. at 331-32.

46. A possible exception to this characterization may be made for plaintiffs seeking summary judgment on affirmative defenses or counterclaims. This article considers such use of summary judgment as anomalous. Facilitating summary judgment on counterclaims, for example, would do little to relieve the strain on the judiciary since this would leave the main action intact.

47. Celotex, 477 U.S. at 323. 
district court--that there is an absence of evidence to support the nonmoving party's case."48 Under this standard, a defendant moving for summary judgment stands in the same procedural posture as a movant for a directed verdict under Federal Rule of Civil Procedure 50(a)..$^{49}$

The motion need not be accompanied by affidavits or documentary evidence and may rely solely on pleadings, depositions, interrogatory answers, and admissions on file..$^{50}$ Indeed, as revealed by the facts of Celotex, a moving party may prevail at summary judgment having "made no effort to adduce any evidence, in the form of affidavits or otherwise, to support its motion."51 At bottom, therefore, the significance of Celotex lies in the Court's relieving defendants, in their customary posture as the party moving for summary judgment, ${ }^{52}$ of any significant burden of production to establish affirmatively the absence of material issues of fact in dispute..$^{53}$

Similarly, Celotex recasts the burden of production once shifted to nonmovants to correspond to their ultimate trial burden.

48. Id. at 325 . The application of this standard remains somewhat in doubt due to the peculiarity of the division of the Court in Celotex. Chief Justice Rehnquist delivered the opinion of the Court in which Justices White, Marshall, Powell and O'Cunnor joined. Justice White's critical fifth vote is tempered, however, by a separate concurrence which disagrees with several of the central premises of the Rehnquist opinion. Thus, White states, in apparent rejection of the majority holding, "[i]t is not enough to move for summary judgment without supporting the motion in any way or with a conclusory assertion that the plaintiff has no evidence to prove his case .... It is the defendant's task [as movant] to negate, if he can, the claimed basis for the suit." 477 U.S. at 328. Justice White, who urges remand for consideration of the plaintiff's response to summary judgment, appears even to disagree with the Court's holding, which reverses and remands. Nonetheless, the lower courts have treated the plurality view of summary judgment as controlling. See infra Section I.D. for assessment of district court burdens on defendant-movants.

49. Celotex, 477 U.S. at 323; Anderson v. Liberty Lobby, Inc., 477 U.S. 242, 250 (1986). There are significant differences between the summary judgment and the motion for a directed verdict contexts, the import of which will be developed in the economic analysis in Section $I$ of this article. First, in the motion for directed verdict context, there is no asymmetry in expenditures between the parties because both parties have incurred full pretrial trial expenses and a commensurate share of trial expenses at the point when the motion for a directed verdict is made. Thus, there is no wealth transfer from plaintiff to defendant such as that which results from the asymmetry in expenses at the time of a summary judgment motion. Second, the directed verdict has no appreciable consequences for aggregate expenditures, whereas summary judgment increases the variance of aggregate expenditures. If the summary judgment motion succeeds, the defendant will bear minimal costs and aggregate expenditures will be lower. If the motion fails, however, aggregate expenditures will be increased to the extent that plaintiff's expenditures are not recoverable at trial. Third, unlike the summary judgment context, defendants moving for a directed verdict have no incentive for strategic misuse of a directed verdict motion, for example, to obtain trial preparation information from the plaintiff. Moreover, "the post-trial determination is made on the basis of a compiled record, not an apparent record that is yet to be made and can therefore be appraised only with somewhat greater caution." Carrington, supra note 8, at 2097-98. For a comparison of practice under Rules 56 and 50, see Stempel, A Distorted Mirror: The Supreme Court's Shimmering View of Summary Judgment, Directed Verdict, and the Adjudication Process, 49 OHio ST. L. J. 95, 144-59 (1988).

50. 477 U.S. at 324.

51. Id. at 321, quoting Catrett v. Johns-Manville Sales Corp., 756 F.2d 181, 184 (D.C. Cir. 1985) (emphasis in original).

52. See Schwarzer, Summary Judgment: A Proposed Revision of Rule 56, 110 F.R.D. 213, 216 (1986) (motion for summary judgment by party having ultimate burden of proof at trial is "relatively rare case").

53. The Celotex opinions leave untouched the question of the proper burden of production to be borne by a movant who would bear the ultimate burden of proof at trial-i.e., a plaintiff moving for summary judgment. Presumably, the movant under such circumstances would still be held to the Adickes standard. 
Rule 56(c) mandates the entry of summary judgment, after adequate time for discovery and upon motion, against a party who fails to make a showing sufficient to establish the existence of an element essential to that party's case, and on which the party will bear the burden of proof at trial. ${ }^{54}$

Thus, Celotex alters the requirements of summary judgment for both the movant and nonmovant to correspond to each party's ultimate burdens at trial. This alteration completes the shift from summary judgment as a plaintiff's motion prior to the promulgation of the Federal Rules to a defendant's motion under Celotex. By streamlining the production required of a movant without the ultimate burden of proof, Celotex facilitates recourse to summary judgment by defendants. Similarly, by then placing the burden of production upon the nonmovant to come forward with evidence of the full range of facts in dispute, the Court enhanced the incentives for defendants seeking to avail themselves of this procedural device. ${ }^{55}$

The Celotex Court's direction on remand that evidentiary issues be considered as part of the summary judgment inquiry, confirms the prodefendant departure from Adickes. The summary judgment standard developed through Adickes would allow a plaintiff-nonmovant to escape summary judgment so long as defendant-movant had not conclusively foreclosed the possibility that she might persuade a jury of her claim, even if only inferentially. In Celotex, by contrast, the Court acknowledged that the record contained documents submitted by plaintiff supporting her position on material issues in the case, yet nonetheless remanded the case for careful examination of the admissibility of these documents. ${ }^{56}$

54. 477 U.S. at 322; see also id. at $324 \mathrm{n} .5$ (citing articles by Louis and Currie urging that summary judgment be recast to reflect the ultimate trial burdens).

55. The threshold showing from defendants may indeed prove to be extraordinarily limited:

Something close to a one page form motion by defendant can throw on the plaintiff the responsibility to dredge, structure, collate and cross-reference all materials in the file to make them available to the judge before trial. Because the material must be reduced to a coherently structured written form, this task can sometimes take as long or longer than actually trying the case.

Risinger, Another Step in the Counter-Revolution: A Summary Judgment on the Supreme Court's New Approach to Summary Judgment, 54 BROOKLYN L. REV. 35, 41 (1988).

56. The Court's dicta on this issue are particularly puzzling. As Rehnquist acknowledges, the record contained sworn deposition testimony supporting plaintiff's claim, a letter from a potential witness asserting plaintiff's version of the critical facts at issue, and a third letter of support for the main proposition in the case. 477 U.S. at 320 . Since defendant did not support its motion with any affidavits, this evidence remained uncontroverted. The Court determined that the evidence was insufficient to defeat the summary judgment motion absent a finding that this evidence would be admissible at trial. See also 477 U.S. at 320-22. There is nothing in the language of Rule 56(c), which speaks only of the presence or absence of genuine issues as to any material fact, that would indicate that plaintiff's evidence must satisfy a hearsay standard. See Nelken, supra note 39, at 72-77 (criticizing Court's treatment of admissibility of evidence issue). On remand, the D.C. Circuit determined that plaintiff's evidence would have been admissible over hearsay objections and, consequently, again denied summary judgment. Catrett v. Johns-Manville Sales Corp., 826 F.2d 33, 37-38 (D.C. Cir. 1987), cert. denied, 108 S. Ct. 1028 (1988). 
By directing lower courts to inquire into evidentiary sufficiency at the summary judgment stage, the Supreme Court opened the door to pretrial adjudication on the merits, regardless of whether the district judge would be constitutionally empowered to sit as the ultimate trier of fact. Thus, even documents that raise genuine issues of material fact may be insufficient for the purpose of withstanding a summary judgment motion if they do not meet the standards of admissibility that would prevail at trial. As confirmed by Anderson, "in ruling on a motion for summary judgment, the judge must view the evidence presented through the prism of the substantive evidentiary burden." 57 It is hard to imagine that the record in Adickes, which contained no evidence at all on the issue of conspiracy or scienter, would have withstood any evidentiary scrutiny. ${ }^{58}$

Primarily, Celotex reordered the burdens facing each party at the summary judgment stage to mirror the ultimate burdens that each party would bear at trial, thereby greatly reducing the demands made upon defendant-movants. The introduction of evidentiary requirements reflecting those at trial, however, takes summary judgment one step beyond simply easing the burden on movants. Read in conjunction with Anderson and Matsushita, Celotex doctrinally approves a new era of summary adjudication. ${ }^{59}$

\section{B. Evidentiary Review Under Summary Judgment}

The new, post-Celotex direction of summary judgment is reinforced by the accompanying cases of the trilogy, Anderson and Matsushita. Whereas Celotex facilitates the process of bringing a summary judgment motion before the court, Anderson and Matsushita increase the chances that a trial court will grant summary judgment. These cases move decisively beyond the position that the district court, passing on a motion for summary judgment, acts primarily as a guarantor that some issues of material fact will be in dispute prior to submission of the case to the trier of fact. Rather, they expand the discretionary authority given to the district courts by allowing broad pretrial evidentiary review.

This is most clearly evident in Anderson, a defamation action involving columnist Jack Anderson which raised the issue of portrayal of public figures in the institutional press. Anderson presented the Court with a chance to define

57. 477 U.S. at 254.

58. Justice Brennan's dissent in Anderson convincingly argues that had the court examined evidentiary sufficiency in Adickes, "we clearly would have had to affirm, rather than reverse, the lower courts, since in that case there was no admissible evidence submitted by petitioner, and a significant amount of evidence presented by the defendant tending to rebut the existence of a conspiracy." 477 U.S. at 263 (Brennan, J., dissenting). In fact, the sum of the nonmovant's case was "an unrebutted assertion that a Kress employee and a policeman were in the same room at the time of the alleged constitutional violation." Id. at 263-64.

59. Friedenthal, supra note 20 , at $771 \& \mathrm{n} .12$ (cases signaling a turn toward greater approval of summary dispositions). 
the role of the district court in summary judgment in the context of the tension between common law defamation and the constitutional protections afforded the investigative media. Since New York Times v. Sullivan, ${ }^{60}$ the Supreme Court has repeatedly expressed its concern for the chilling effect of such defamation actions on fundamental First Amendment freedoms. ${ }^{61}$ Nevertheless, the Court has repeatedly asserted its refusal "to grant special procedural protections to defendants in libel and defamation actions in addition to the constitutional protections embodied in the substantive laws." ${ }^{62}$ Thus, the Court in Anderson confronted the combination of a constitutionally disfavored cause of action and concern for the chilling effect of the litigation itself without any procedural shortcut for avoiding trial. This made Anderson a ripe case for the Court to extend the availability of summary judgment.

Whereas Celotex directed the courts below only to inquire into the evidentiary sufficiency of the record, Anderson recast summary judgment into the mold of a motion for a directed verdict. ${ }^{63}$ Thus, "[t]he mere existence of a scintilla of evidence in support of the plaintiff's position will be insufficient .... The judge's inquiry, therefore, unavoidably asks whether reasonable jurors could find by a preponderance of the evidence that the plaintiff is entitled to a verdict." ${ }^{64}$ Judges examining the record on a motion for summary judgment are directed to determine whether the evidence "presents a sufficient disagreement" or "is so one-sided that one party must prevail as a matter of law." 65 In discharging this task, courts must "bear in mind the actual quantum and quantity of proof necessary to support liability," in order to determine whether evidence is of "insufficient caliber or quality" as to preclude trial on the merits. ${ }^{66}$ As observed by Justice Brennan in dissent, this approach marks a significant departure from the traditional view that the measurement of the "caliber and quantity" of evidence "could only be performed by weighing the evidence": "[T]he Court's opinion is . . full of language which could surely be understood as an invitation-if not an instruction- to trial courts to assess and weigh evidence much as a juror would."

60. 376 U.S. 254 (1964).

61. 376 U.S. at 279-80; see also Gertz v. Robert Welch, Inc., 418 U.S. 323, 342-43 (1974) (concern for the potential chilling effect of defamation actions is partially reflected in "clear and convincing" standard of proof for libel claims, as opposed to preponderance of evidence standard common to most civil litigation).

62. Calder v. Jones, 465 U.S. 783, $790-91$ (1984); $c f$. Hazard, Discovery Vices and Trans-Substantive Virtues in the Federal Rules of Civil Procedure, 137 U. PA. L. REv. 2237, 2244 (1989) (criticizing conventional view that Federal Rules "indiscriminately govern all kinds and types of litigation").

63. 477 U.S. at 250.

64. Id. at 252.

65. Id. at 251-52.

66. Id. at 254. See Kamp, Federal Adjudication of Facts: The New Regime, 12 AM. J. TRIAL ADVoc. 437, 456-67 (1989) (proof and support necessary in federal adjudication).

67. Anderson, 477 U.S. at 266 (Brennan, J., dissenting) (emphasis in original). For an assessment of pretrilogy summary judgment, see 10A C. WRIGHT, A. MIILER \& M. KANE, FEDERAL PRACTICE AND PROCEDURE § 2730 (2d ed. 1983) (summary judgment improper where credibility issues are present); id. at $\$ 2732$ (no summary judgment where complicated fact patterns present). 
Perhaps more striking than the language in Anderson is the actual holding in Matsushita, a massive antitrust case involving the alleged dumping of Japanese televisions on the American market. Here the Court upheld a grant of summary judgment against plaintiffs, American manufacturers, despite the submission of detailed and unrebutted expert reports supporting plaintiffs' claims. ${ }^{68}$ The Court required the American manufacturers to "come forward with more persuasive evidence to support their claim than would otherwise be necessary," because "the claim was one that simply makes no economic sense." ${ }^{19}$ The Court found support for the proposition that the claim "makes no economic sense" not from the record below but from a "consensus among commentators that predatory pricing schemes are rarely tried, and even more rarely successful."70 The Court reached even further into the realm of factfinding ${ }^{71}$ to add, "[t]he alleged conspiracy's failure to achieve its ends in the two decades of its asserted operation is strong evidence that the conspiracy does not in fact exist." "72 The Court's venture into economic theory provoked yet another vigorous dissent, this time by Justice White who read in the majority opinion an invitation to the district judge to "go beyond the traditional summary

68. Among the evidence was a three-volume report by Dr. Horace J. DePodwin, Dean of the Graduate School of Business Administration at Rutgers University characterized by the district court as "by far the most careful, scholarly, and disinterested of the reports submitted by the plaintiffs' expert witnesses." Zenith Radio Corp. v. Matsushita Elec. Indus. Co., 505 F. Supp. 1313, 1334 (E.D. Pa. 1980). See also Stempel, supra note 49, at 108-14 (reviewing factual record in Matsushita). The district court based its summary judgment determination, in part, on its ruling that the report was inadmissible. The appellate court subsequently overturned the district court's exclusion of this report. In re Japanese Electronic Products Antitrust Litigation, 723 F.2d 238, 280-81 (3d Cir. 1983). The Supreme Court did not address the evidentiary issue, thereby leaving the Third Circuit's ruling on admissibility untouched. See Matsushita, 475 U.S. at 582.

69. Matsushita, 475 U.S. at 587.

70. Id. at 589. The Court's "consensus" regarding predatory pricing drew primarily from a defined school of thought commonly associated with the law and economics movement at the University of Chicago. See, e.g., Easterbrook, Predatory Strategies and Counterstrategies, 48 U. CHI. L. REV. 263, 268 (1981). There are two fundamental problems with the Court's analysis. First, even if we assume the fact that predatory pricing is rare, we do not thereby resolve the issue whether it was present in the particular case of Japanese electronics manufacturers. Second, even if a consensus of commentators could be binding on parties before the Court, the views of the commentators cited by the Court do not rise to the level of a consensus, as evidenced by the significant literature concerning the identification and prevention of the very conduct the Court dismisses as "rare"-predatory pricing. See, e.g., Baumol, Quasi-Permanence of Price Reductions: A Policy for Prevention of Predatory Pricing, 89 YALE L.J. 1 (1979); Joskow \& Klevorick, A Framework for Analyzing Predatory Pricing Policy, 89 YALE L.J. 213 (1979).

71. The Court's widespread review of the facts in Matsushita has prompted commentators to see in this case "a novel willingness to weigh the proffered facts to determine whether a dispute of fact is actually 'genuine." Warren \& Cranston, Summary Judgment after Matsushita, 1 ANTITRUST 12 (Summer 1987).

72. Matsushita, 475 U.S. at 592. According to the Supreme Court, the claim that a goal of the conspiracy was to drive Zenith out of the market could not withstand summary judgment since "[the data in the record strongly suggest that that goal is yet far distant." Id. at 591. Since the publication of this opinion, Zenith, the last extant American manufacturer of televisions, has expressed interest in selling off its remaining television manufacturing division. See Rudd, Zenith Posts Quarter Loss of \$4 Million, Chicago Tribune, Apr. 26, 1989, $\S 3$ (Business), at 3, col. 3. There have also been significant concerns about collusion and predatory pricing by Japanese semiconductor manufacturers, resulting in the voluntary establishment of minimum-pricing systems for certain types of Japanese-produced microchips. See Pollack, Europe Sets Prices for Japan's Chips, N.Y. Times, Jan. 24, 1990, at D5, col. 4. 
judgment inquiry and decide for himself whether the weight of the evidence favors the plaintiff." 73

As a consequence of the trilogy, the Court appears to have transformed summary judgment from a mechanism for assuring a modicum of genuine dispute in cases set for trial to a full dress-rehearsal for trial with legal burdens and evidentiary standards to match those that would apply at trial. ${ }^{74}$ Indeed, the trilogy can be read to "endorse summary judgment as a substitute for trial." ${ }^{.75}$ Neither the dress-rehearsal analogy nor the trial analogy should obscure the critical difference between summary judgment and trial: there is no jury sitting as trier of fact and only plaintiffs are at risk of adverse final judgment. $^{76}$

\section{Lower Court Applications of the Summary Judgment Trilogy}

The summary judgment trilogy alters the conventional wisdom concerning the limited availability of Rule 56. Traditionally, courts adhered to the view that summary judgment should be "cautiously invoked" 77 and that it should be denied wherever there is the "slightest doubt as to the facts" involved. ${ }^{78}$ Long lines of cases held that the burden of proving the absence of material facts in dispute rests with movants. ${ }^{79}$ Additionally, courts would not grant

73. Matsushita, 475 U.S. at 600 (White, J., dissenting). The trail of Justice White through the trilogy is rather mystifying. White provides the crucial fifth vote in Celotex, though apparently disagreeing with the actual holding of the case. See Celotex, 477 U.S. 317,328 (White, J., concurring). White then authors the majority opinion in Anderson which, in terms of its actual formulation of the altered summary judgment standard for district court fact finding, is the most sweeping of the trilogy. Finally, White authors the bitter dissent in Matsushita, accusing the majority of overturning settled law in assigning to the district judge "the job of determining if the evidence makes the inference of conspiracy more probable than not ...." 475 U.S. at 601 .

74. See Mullenix, Summary Judgment: Taming the Beast of Burdens, 10 AM. J. TRIAL ADVOC. 433, 468 (1987) ("By reading backwards from the directed verdict the Court transformed summary procedure into a full trial-before-trial."); Kamp, Federal Adjudication of Facts: The New Regime, 12 AM. J. TRIAL ADVOC. 437, 456-57 (1989) (trilogy has "turned the summary judgment motion into a mini-trial").

75. Marcus, Completing Equity's Conquest? Reflections on the Future of Trial Under the Federal Rules of Civil Procedure, 50 U. PITT. L. REV. 725, 740 (1989).

76. The Supreme Court opened, and did not resolve, yet another issue of critical importance to plaintiffnonmovants. If summary judgment post-Celotex is to be viewed as a proving ground for plaintiffs to earn their entitlement to go to trial, what becomes of issues or evidence not presented to the district court in defense against the summary judgment motion? Conceivably, if trial is to be made available only insofar as claims and evidentiary proof satisfy the higher, post-trilogy standard, plaintiffs may be barred at trial from introducing evidence or raising arguments for all claims for which they had not established the existence of a genuine issue of material fact in dispute. Justice Rehnquist's opinion for the Court in Celotex raises this problem in defending the expansive new role of the district court when he refers to the district courts being "widely acknowledged to possess the power to enter summary judgments sua sponte, so long as the losing party was on notice that she had to come forward with all of her evidence." Celotex, 477 U.S. at 326 (emphasis added).

77. See 10 C. WRIGHT, A. MILLER \& M. KANE, supra note $13, \S 2712$, at 587.

78. See id., $\S 2712$, at 583 .

79. See, e.g., Bell v. Cameron Meadows Land Co., 669 F.2d 1278, 1284 (9th Cir. 1982); Mark v. Cape Elizabeth School Bd., 553 F.2d 720, 722 (1st Cir. 1977) (movant has affirmative burden of demonstrating no factual dispute, "even though, as a defendant, he would have no burden if the case were to go to trial"). 
summary judgment based on a weighing of factual inferences. ${ }^{80}$ Nor, would they generally grant summary judgment when the issues in dispute turned on subjective factors such as intent, knowledge or motivation. ${ }^{81}$

A post-trilogy review of lower court decisions reveals a widespread and dramatic recasting of summary judgment doctrine by the lower courts. This is clearly evident in the revision of the movant's burden in light of Celotex ${ }^{82}$ and in the eased standards for the grant of summary judgment evident in Anderson and Matsushita. ${ }^{83}$ Courts have shown a new willingness to resolve issues of

10A C. WRIGHT, A. MILER \& M. KANE, supra note $67, \S 2727$, at 121-28.

80. See, e.g., Redna Marine Corp. v. Poland, 46 F.R.D. 81, 85 (S.D.N.Y. 1969); see also 10 C. WRIGHT, A. MILLER \& M. KANE, supra note $13, \S 2712$.

81. See, e.g., Thombrough v. Columbus \& Freenville R.R., 760 F.2d 633, 640 (5th Cir. 1985); Archer v. Dutcher, 733 F.2d 14, 16 (2d Cir. 1984) (affidavit raising issue of intentional infliction of tort sufficient to survive summary judgment); Vaughn v. Teledyne, Inc., 628 F.2d 1214, 1220 (9th Cir. 1980) ("Cases where intent is a primary issue generally are inappropriate for summary judgment."); Charbonnages de France v. Smith, 597 F.2d 406, 414-15 (4th Cir. 1979); 10A C.WRIGHT, A. MILLER \& M. KANE, supra note $67, \S \S 2727$ n.20, 2730.

82. See Beatty v. Washington Metro. Area Transit Auth., 860 F.2d 1117, 1120 (D.C. Cir. 1988) (relying on Celotex to reject requirement that movant support its motions with affidavits or other evidence negating the nonmovant's claim, but indicating that movant still must argue in favor of motion for summary judgment); Texas v. Allan Const. Co., 851 F.2d 1526, 1534 (5th Cir. 1988) (nonmovant must establish issues of material fact "even where the party moving for summary judgment has not offered evidence negating the opponent's claim"); Kaufmann v. Puerto Rico Tel. Co., 841 F.2d 1169, 1172 (1st Cir. 1988) (summary judgment proper when nonmovant fails to support essential element of case); Honore v. Douglas, 833 F.2d 565,567 (5th Cir. 1987) (movant for summary judgment must make initial showing negating "any disputed, material fact;" party opposing motion must then "offer evidence reflecting the existence of one or more genuine issues of material fact); Lake Nacimento Ranch Co. v. County of San Luis Obispo, 830 F.2d 977, 980 (9th Cir. 1987) (no requirement that summary judgment motion be supported by affidavits or other materials); Pocahantas Supreme Coal Co. v. Bethlehem Steel Corp., 828 F.2d 211, 217 (4th Cir. 1987) (summary judgment proper after movant points out deficiencies in plaintiff's case and plaintiff fails to forecast hard proof); Windon Third Oil and Gas Drilling Partnership v. FDIC, 805 F.2d 342, 346 (10th Cir. 1986), cert. denied, 480 U.S. 947 (1987) (movant's burden "cannot be enhanced to require his proof of a negative"). See generally, Note, Federal Summary Judgment: The 'New' Workhorse for an Overburdened Federal Court System, 20 U.C. DAVIS L. REV. 955, 968-78 (1987) (reviewing lower court decisions in light of Celotex).

83. The changes are observable in the recasting of summary judgment into a preferred procedure in the Second Circuit, once a court of stalwart opposition to the use of summary judgment. See H.L. Hayden Co. v. Siemens Medical Sys., 879 F.2d 1005, 1011-12 (2d Cir. 1989) ("encourage use of summary judgment in complex cases to avoid unnecessary trials"); R.C. Bigelow, Inc. v. Unilever N.V., 867 F.2d 102, 107 (2d Cir. 1989) (discussion of liberal summary judgment standard in antitrust suit); Kronfeld v. TWA, Inc., 832 F.2d 726, 739 (2d Cir. 1987) (Miner, J., dissenting) (where appropriate, summary judgment "should be granted without hesitation"); Apex Oil Co. v. DiMauro, 822 F.2d 246, 252 (2d Cir. 1987) (use of summary judgment encouraged); Knight v. U.S. Fire Ins. Co., 804 F.2d 9, 11-12 (2d Cir. 1986) ("It appears that in this circuit some litigants are reluctant to make full use of the summary judgment process because of their perception that this court is unsympathetic to such motions and frequently reverses grants of summary judgment. Whatever may have been the accuracy of this view in years gone by, it is decidedly inaccurate at the present time .... .), cert. denied, 480 U.S. 932 (1987). But see Donahue v. Windsor Locks Bd. of Fire Comm'rs, 834 F.2d 54, 57 (2d Cir. 1987) (decrying "frequency of cases in which [summary judgment] is granted improvidently"). A similar expansion is occurring in administrative tribunals, see Fletcher \& Kunstadt, The Forty-Second Year of Administration of the Lanham Trademark Act of 1946, 79 TRADEMARK REP. 757,757 (1989) (describing expanded use of summary judgment by the Trademark Trial and Appeal Board and the Court of Appeals for the Federal Circuit), and in the current practice of determining, at summary judgment, whether works subject to copyright infringement claims are "substantially similar." See Frybarger v. IBM Corp., 812 F.2d 525 (9th Cir. 1987); Walker v. Time Life Films, Inc., 784 F.2d 44 (2d Cir. 1986); Evans v. Wallace Berrie \& Co., 681 F. Supp. 813 (S.D. Fla. 1988). 
intent or motive at the summary judgment stage, ${ }^{84}$ and, in the extreme version, to grant summary judgment where "'taken as a whole, [plaintiffs' evidence does not] exclude other reasonable hypotheses with a fair amount of certainty...." "ns

Lower federal courts have found that the trilogy "has increased the utility of summary judgment. ${ }^{386}$ Courts almost uniformly regard the movant's burden under Celotex to be satisfied even by a "meager" showing ${ }^{87}$ yet mandate that, even under such circumstances, "the non-moving party must shoulder a heavy burden in order to survive summary judgment ...." ${ }^{88}$ Considerable evidence also supports the proposition that courts have taken Matsushita and Anderson as an invitation to review more aggressively factual and evidentiary issues. Thus, according to the Ninth Circuit, "[i]f the factual context makes nonmoving party's claim implausible, that party must come forward with more persuasive evidence than would otherwise be necessary to show that there is a genuine issue for trial." ${ }^{\text {89 }}$ Indeed, the Ninth Circuit has been at the forefront of expanding evidentiary review at the summary judgment stage of litigation, stating: "No longer can it be argued that any disagreement about a material issue of fact precludes the use of summary judgment." 90

There is evidence in the post-trilogy case law that summary judgment has moved beyond its originally intended role as a guarantor of the existence of material issues to be resolved at trial and has been transformed into a mechanism to assess plaintiff's likelihood of prevailing at trial. Consequently, courts

84. See Marcial v. Coronet Ins. Co., 880 F.2d 954, 960-61 (7th Cir. 1989) (upholding grant of summary judgment against claim of intent to defraud); Henn v. National Geographic Soc'y, 819 F.2d 824 (7th Cir. 1987) (employment discrimination context); Dale v. Chicago Tribune Co., 797 F.2d 458 (7th Cir. 1986) (employment discrimination and ERISA context); Indiana Grocery Co. v. Super Valu Stores, Inc., 684 F. Supp. 561 (S.D. Ind. 1988) (antitrust context); Wehrly v. American Motors Sales Corp., 678 F.Supp. 1366 (N.D. Ind. 1988) (age discrimination in employment context); Vargas v. Calabrese, Civ. No. 85-4725, at 24 (D.N.J., opinion of Feb 22, 1988) (on file with author). In Vargas, the district court granted summary judgment to the lead defendant in a civil rights conspiracy case based on an affidavit and deposition testimony of the defendant that she intended no harm. In granting summary judgment, the Vargas decision weighed the evidence produced in close to 1,000 pages of affidavits, deposition testimony and public documents raising inferential issues of conspiracy. See Cartagena, The New Summary Judgment Motion, in 4 CIVIL RIGHTS LITIGATION AND ATTORNEY FEES ANNUAL HANDBOOK 115, 115-16 (B. Wolvovitz, ed. 1988) (discussing application of trilogy in Vargas). One of the present authors, Professor Issacharoff, served as co-counsel with Mr. Cartagena in Vargas.

85. Bouillion v. Eli Lilly \& Co., 677 F.Supp. 467, 471 (W.D. La. 1988) (quoting Norris v. Bell Helicopter Textron, 495 So. 2d 976, 982 (La. App. 1986), cert. denied, 499 So. 2d 85 (La. 1987)).

86. California Architectural Bldg. Prod. v. Franciscan Ceramics, Inc., 818 F.2d 1466, 1468 (9th Cir. 1987).

87. Pope v. Mississippi Real Estate Comm'n, 695 F. Supp. 253, 262 (N.D. Miss. 1988).

88. Id.

89. Franciscan Ceramics, 818 F.2d at 1468 (emphasis in original). Similarly, "it must be apparent on summary judgment that Plaintiff will be able to present evidence at trial sufficient to allow a reasonable jury to find that Plaintiff has proved his case by a preponderance." Wilson v. Popp Yarn Corp., 680 F. Supp. 208, 210 (W.D.N.C. 1988) (emphasis added).

90. Franciscan Ceramics, 818 F.2d at 1468. See also Saenz v. Playboy Enterprises, Inc., 841 F.2d 1309, 1317-19 (7th Cir. 1988) (summary judgment proper where actual malice in libel case could not be established according to appellate review of "caliber or quality" of evidence). 
are utilizing summary judgment where the plaintiff-nonmovant is unable to persuade the district court that judgment for the defendant would be foreclosed if the case were to come to trial. A particularly striking example is found in Viterbo v. Dow Chemical Co., ${ }^{91}$ in which the Fifth Circuit affirmed the grant of summary judgment to a chemical manufacturer in a tort suit involving exposure to a pesticide produced by the defendant. On facts reminiscent of Matsushita, the district court granted summary judgment after excluding the proposed testimony of plaintiff's expert witness, one Dr. Alfred Johnson. The case is striking because the parties did not dispute the plaintiff's exposure to the pesticide, the plaintiff's symptomology, or the fact that Dr. Johnson's tests "support[ed] a conclusion that Viterbo had suffered from some sort of toxic reaction." 92 Nonetheless, despite the court's acceptance of Dr. Johnson's qualification as an expert and the absence of any opposing expert testimony proffered by the defendant, the district court rejected Dr. Johnson's testimony on the basis of its own assessment of the evidentiary weight to be given to his testimony-rather than its admissibility under the rules of evidence..$^{93}$ The critical issue, according to the Fifth Circuit, was Johnson's admission that "Viterbo's symptoms could have numerous causes ...." 94 As a consequence of the plaintiff's expert's failure to foreclose the possibility of a jury finding for the defendant, ${ }^{95}$ the Fifth Circuit found proper the district court's grant of summary judgment on the issue of causation..$^{96}$

91. 826 F.2d 420 (5th Cir. 1987).

92. Id. at 423 .

93. The district court concluded that Dr. Johnson's opinions were "subjective," that Viterbo failed to react in the expected manner to subsequent exposures, that blood tests performed by Dr. Johnson revealed the presence of other toxic substances, and that the reactions could have been attributed to a number of causes. In addition, Dr. Johnson had relied on animal experiments involving exposure levels exceeding that which Viterbo had experienced. Id. at 423-24.

94. Id. at 424.

95. Viterbo is not unique in resolving evidentiary issues of scientific testimony at the summary judgment stage after the Supreme Court's trilogy. In In re Paoli Railroad Yard PCB Litigation, 706 F. Supp. 358 (E.D. Pa. 1988), for example, the district court similarly rejected plaintiffs' expert testimony at the summary judgment stage. In granting defendants' motion for summary judgment, the court determined that plaintiffs' expert reports would not be admitted, inter alia, because they attempted to identify "the cause of human illness based upon the results of animal tests," 706 F. Supp. at 367, and because they attempted to rely on scientific studies of the long-term effects of exposures to PCBs in Japan and Taiwan in the late 1960's. According to the court, "[d]efendants argue[d] that it is bad science, and therefore inadmissible evidence, to base conclusions regarding the health of our plaintiffs on what happened to these people." Id. at 368 .

96. The use of summary judgment to deny access to the jury seems particularly prevalent in toxic tort cases where judges do not find the evidence probative. See, e.g., Washington v. Armstrong World Indus. Inc., 839 F.2d 1121 (5th Cir. 1988) (rejecting claim of link between asbestos exposure and colon cancer); Felgenhauer v. Texaco, Inc., No. 85-3671 (E.D. Pa. Nov. 30, 1987) (1987 U.S. Dist. LEXIS 11258) (rejecting expert witness' claim of link between defendant's product and liver damage); see generally, Brennan, Helping Courts With Toxic Torts: Some Proposals Regarding Alternative Methods for Presenting and Assessing Scientific Evidence in Common Law Courts, 51 U. PITT. L. REV. 1, 9 n.40 and accompanying text (1989) (listing cases in which judicial skepticism of scientific testimony led to granting of summary judgment). 
Equally striking is the use of factfinding under summary judgment in the en banc decision of the Seventh Circuit in UAW v. Johnson Controls. ${ }^{97}$ In a sex discrimination case challenging the exclusion of women of child-bearing age from industrial positions with significant lead exposures, the court relied on extensive factual reviews of contested scientific evidence. Thus, the exposure levels to lead in Johnson Controls were deemed significant based on the testimony of a defense expert that identified only one child with a history of hyperactivity that "could very well and probably was due to the lead that he had,"98 as a result of his mother's exposure to lead while pregnant (even though she did not work at Johnson Controls). By contrast, the court rejected the opinions of plaintiffs' experts that exposure problems were not confined to women. ${ }^{99}$ The plaintiffs' experts supported their testimony with evidence from two scientific studies, the first showing a correlation between male lead exposure and changes in sperm shape and the second using animal studies to indicate a relationship between male exposures to toxic substances and birth defects. ${ }^{100}$ As expressed in the dissenting opinion of Judge Easterbrook, the employer's claim that only females' exposure to lead would endanger offspring ran contrary to "an impressive array of studies linking lead with injury to the male reproductive system, and thence to offspring."101 Despite the conflicts on material issues absolutely central to the disputed exclusion of women from the workforce, the Johnson Control plaintiffs, in a fashion similar to Viterbo, failed to survive summary judgment.

\section{Beyond the Doctrines}

Any assessment of the actual impact of the summary judgment trilogy in the lifestream of litigation should look beyond the doctrinal level to see how the alterations have played out in the district courts. ${ }^{102}$ To this end, we have reviewed all the published federal court opinions in the first quarter of 1988 that refer to Celotex, ${ }^{103}$ a total of 192 opinions. We eliminated 52 of the 192

97. 886 F.2d 871 (7th Cir. 1989) (en banc), cert. granted, 110 S. Ct. 1522 (1990).

98. Id. at 877 .

99. Id. at $889-90$.

100. Id. at 889.

101. Id. at 918 . The court's discounting of these studies forms one of the issues on which the Supreme Court has granted certiorari. 59 U.S.L.W. 3022 (1990).

102. See Carrington, supra note 8, at 2093 (commenting that "[i]t is still early to evaluate the trilogy's effect on the realities of federal practice").

103. Research revealed that district courts routinely refer to Celotex in passing on motions for summary judgment. The database was created by a Westlaw search for Celotex. The use of published decisions to assess the impact of the trilogy in the district courts has limitations. Since only a small percentage of cases are litigated to judgment, and since not all of these result in published opinions, the sampling problems are readily apparent. Nonetheless, the decision as to which opinions to publish is made by the district court judges with the clear aim of informing the bar about significant legal developments. Thus, our decision to rely on published opinions is justified by the critical role of published opinions in shaping the perception among the bar of how the courts are handling procedural issues. We selected 1988 as the year to review 
on the grounds that they involved cross-motions for summary judgment where, of necessity, the parties have represented to the court that legal issues predominate and there are no issues of material fact in dispute. This left 140 contested summary judgment motions from which the following observations may be drawn:

1. Summary judgment is a defendant's motion. Of the 140 motions, 122 were made by defendants and 18 by plaintiffs.

2. The courts are encouraging the filing of summary judgment motions. Although our analysis is limited to reported cases in which a higher proportion of granted summary judgment motions would be expected, ${ }^{104}$ the unmistakable message to the bar is that district courts are highly receptive to summary judgment motions and, indeed, that such motions are being freely granted. Thus, summary judgments were awarded defendants in whole or part in 98 cases and denied in only 24 (including one in which the complaint was dismissed on other grounds). Summary judgments were awarded to plaintiffs in 16 cases and denied in $2 .{ }^{105}$

3. At the doctrinal level, courts are not reviewing the sufficiency of the defendant/movant's production. In 59 of the 98 cases (60\%) in which judgment was entered for defendant, the district court granted summary judgment without any discussion of the sufficiency of the defendant's production in support of the summary judgment motion. Moreover, the courts in 12 of these cases did not discuss any evidence or documentation introduced by defendants in support of the summary judgment motion; instead, they based awards solely on the perceived insufficiency of plaintiffs' production.

This review of the 1988 district court caselaw is fully consistent with a recent study of all reported antitrust conspiracy decisions in the aftermath of Matsushita. ${ }^{106}$ The study found that summary judgment was entered for defendants in 64 cases, that it was denied in only 13 cases, and that in no case was summary judgment entered for plaintiffs; the study reported no decisions entered after trial on the merits in an antitrust conspiracy case. ${ }^{107}$

\footnotetext{
in order to allow time for the trilogy to be absorbed into general legal practice.

104. Denials of summary judgment based on the existence of disputed factual issues appear less likely to result in published opinions. Nonetheless, a sampling of published opinions is instructive because of the educational role these opinions serve in informing the practice of the bar. A high level of grants of summary judgment in published opinions thus will likely generate a larger summary judgment motion practice, despite the fact that a significant portion of the additional motions for summary judgment will not be granted.

105. This group includes General Battery Int'l Corp. v. Union de Servicios y Mantenimientos Industriales de Puerto Rico, 678 F.Supp. 33 (D.P.R. 1988), in which the court denied plaintiff's motion for summary judgment and entered summary judgment sua sponte for defendant.

106. Note, Summary Judgment in Federal Court: New Maxims for a Familiar Rule, 34 N.Y.L. SCH. L. REV. 201, 218 \& n.125 (1989).

107. Id.
} 
In sum, as revealed by the doctrinal and empirical reviews of the lower courts, the increased availability of summary judgment alters the balance of power between plaintiffs and defendants in the pretrial phases of litigation by raising both the costs and risks to plaintiffs at the summary judgment stage while diminishing both for defendants. By matching the doctrinal analysis of the courts with their practices as revealed through published opinions it becomes evident that the summary judgment trilogy allows for summary judgment without supporting affidavits, documents or other forms of evidence of record, so long as the assertion of the absence of material facts in dispute is made by the party not bearing the ultimate burden of proof-typically the defendant.

The consequences of such summary judgment procedures are twofold, as we will elaborate in the economic analysis that follows. First, the courts have sanctioned a cost-free motion for summary judgment in which the defendantmovant need not bear the cost of creating a record in order to put the issue of summary adjudication before the court. Second, the new summary judgment standards increase the likelihood of a grant of summary judgment by encouraging district courts to be more active in identifying the "genuine" issues that require trial. Put another way, the Supreme Court trilogy encourages the grant of summary judgment through an expansive view of the role of the trial court in determining what issues merit presentation to the ultimate trier of fact. This in turn significantly increases the risk of judgment against the nonmovant-typically the plaintiff-and drives up the costs of perfecting the evidentiary record against the risk of such judgment. Inspired by cases such as Anderson, the new summary judgment standards are accompanied by an increased attentiveness to the "due process" rights of the movants to quickly remove cases from the federal dockets. As expressed by one district court, "Rule 56 must be read ... as intended not just to protect nonmovants with real claims but also to protect the rights of movants to dispose of claims without a sufficient basis to go to trial." ${ }^{108}$

From the defendant's vantagepoint, therefore, the effect of the trilogy is both to facilitate the process for making a summary judgment motion and to increase the likelihood of success of such a motion. Conversely, the trilogy increases the threshold burden on plaintiffs both by making summary judgment more available to defendants and by forcing plaintiffs to shoulder the burden of documenting the merits of their case at an earlier stage of the litigation. ${ }^{109}$ We now turn to the consequences this reordering of procedural burdens in the

108. Mokelis v. Scientific Sys. Serv. Inc., 677 F. Supp. 378, 380 (W.D. Pa. 1988); see also PatersonLeitch Co. v. Massachusetts Mun. Wholesale Elec. Co., 840 F.2d 985, 996 (1st Cir. 1988) (movant entitled to dismissal of factually unfounded suits).

109. As a normative matter, it is difficult to see how such a straight line redirection of the balance of power between the parties can be reconciled with claims that neutrality as between the interests of particular groups of disputants is a "paramount value" in procedural rulemaking. See Carrington, supra note 8, at 2074 (characterizing neutrality as "perhaps a paramount value"). 
summary judgment trilogy creates by examining the altered economic incentives for each party.

\section{AN ECONOMC ANALYSIS OF SUMMARY JUDGMENT}

Having identified the trilogy-produced alterations in summary judgment doctrines, we now examine the predicted consequences of the new standards on the behavior of litigants. These go beyond the simple disposal of meritless cases that appears to have been the main motivation for the revised interpretation. To understand the impact of these alterations, one must examine their effect on the incentives they provide for both parties. ${ }^{110}$ By examining the incentives for settlement or non-settlement at different points in time and the corresponding incentives for escalation of litigation, we assess the anticipated consequences of the trilogy.

Our primary goal is to determine whether summary judgment is likely to achieve the central objective of reducing litigation. To do so, we consider the two ways in which summary judgment affects the extent of litigation: directly, through the disposal of cases, and indirectly, through its impact on settlement. In examining case disposal, we look first to see whether summary judgment will screen cases selectively, eliminating a disproportion of nonmeritorious or "strike suits," relative to other suits. In turning to impact on settlement, however, the analysis is more complex.

The impact of summary judgment on settlement can be measured in two distinct ways: first, by the change in the proportion of cases that are settled prior to trial, including those that settle after an unsuccessful summary judgment bid, and second, by the settlement of cases at the outset of litigation, prior to an anticipated move for summary judgment. The difficulty with these measures is that there are different costs associated with each so they cannot be aggregated into a single measure of settlement. When parties settle after an unsuccessful summary judgment bid, the costs prior to settlement are greater than when parties settle at the outset, since expenses will have already been incurred in the course of the litigation up through the summary judgment stage. To avoid this problem, we also employ, as a measure of settlement, aggregate litigation expenses borne by disputants. This second measure pays heed to the lower costs associated with early settlement.

A second goal is to examine the consequences of summary judgment for the distribution of wealth between plaintiffs and defendants. Again, this impact can be assessed in two ways: by the change in settlement values resulting from

110. See Miller, An Economic Analysis of Rule 68, 15 J. LEGAL STUD. 93, 94 (1986) (examining operation of Rule 68 from this dual-party perspective); Cooter, Marks \& Mnookin, Bargaining in the Shadow of the Law: A Testable Model of Strategic Behavior, 11 J. LEGAL STUD. 225 (1982); Mnookin \& Kornhauser, Bargaining in the Shadow of the Law: The Case of Divorce, 88 YALE L.J. 950 (1979). 
the liberalization of summary judgment and by the change in plaintiffs' willingness to bring cases in the first place. We shall first examine the impact of liberalized summary judgment without reference to additional complications such as the strategic benefit that defendants may realize by forcing a disclosure of plaintiffs' evidence, and without reference to the effect that the particular incentives for repeat players may have in determining when summary judgment is likely to be invoked. In a later section we relax these assumptions to obtain a fuller picture of the ramifications of liberalized summary judgment.

In order to isolate the impact of the availability of summary judgment under the trilogy, we compare the series of decisions faced by litigants in the presence and absence of a summary judgment option. Figures 1 and 2 depict these sequences of decisions in the form of decision trees, the first representing the case of no summary judgment, the second introducing the option of summary judgment. The trees consists of three components: decision points at which one or both parties must make decisions (represented by rectangles); chance outcomes (circles) designating the outcome of litigation; and payoffs (in brackets), with the plaintiff's payoff listed first and the defendant's payoff listed second.

For illustrative purposes we track a hypothetical suit involving specific monetary amounts through the decision tree. A more general algebraic treatment is presented in the appendix. The critical features of our stylized example, designed to replicate the summary judgment standard evolved through the trilogy, are that the defendant has the option of moving for summary judgment, that the option is cost-free to the defendant (in accord with Celotex), and that the plaintiff is the party at risk who must expend substantial resources to defend against the summary judgment motion. ${ }^{111}$

Our illustrative case involves a one million dollar claim in which the plaintiff has an eighty percent chance of success on the merits and in which both parties agree on this likelihood of plaintiff's success. Plaintiff's trial expenses are $\$ 75,000$; defendant expenses are $\$ 50,000 .{ }^{112}$ We assume that

111. These assumptions are a stylized rendition of the standards evolving from the summary judgment trilogy as reflected in the data set at supra text accompanying notes 102-07.

112. The values are fixed for the purposes of the illustrative model. Clearly, the parties will make strategic decisions about how much to spend at trial, and plaintiff will make strategic decisions about how much to spend defending against the summary judgment motion. The formal algebraic treatment of the options available to the parties, contained in the appendix, allows for the full range of decisions that can be made by the parties. 
settlement prior to trial or to the filing of summary judgment motions is costfree.

Figure 1

Decision Tree without Summary Judgment

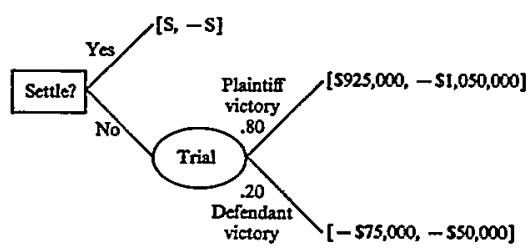

When we introduce the summary judgment option, we assume that the defendant incurs no expenses at the summary judgment stage, while the plaintiff is assumed to spend $\$ 50,000$. Furthermore, we assume half of plaintiff's expenses in defense of the summary judgment motion $(\$ 25,000)$ to be recoverable costs, which will carry forward to trial as expenses that would have been incurred regardless of the summary judgment motion, ${ }^{113}$ and half $(\$ 25,000)$ to be independent costs which would be incurred in defending against the summary judgment motion proper ${ }^{114}$ Thus, having spent $\$ 50,000$ on summary judgment, the plaintiff will only spend $\$ 50,000$ on trial. Together with these levels of expenditures, we assign to the defendant a ten percent chance of prevailing on summary judgment.

113. This is again a stylized assumption, but one that corresponds to the situation confronting plaintiff at the summary judgment stage. Since defense against a summary judgment motion requires the presentation of evidence and affidavits, plaintiff will be forced to turn to the same sources of proof as would be utilized at trial. The organization of documents into exhibits, the preparation of witnesses to secure affidavits, and the marshalling of legal authority in support of plaintiff's claims overlap considerably with the plaintiff's burden going into trial. Plaintiff's summary judgment production is neither completely separate from nor completely congruent with plaintiff's production at trial. We have therefore assigned a partial overlap between plaintiff's production for trial and for summary judgment such that defendant's motion for summary judgment raises plaintiff's absolute costs to the amount that are devoted exclusively to the summary judgment motion and shifts the temporal sequence of that part of plaintiff's expenses that would have been borne at trial independent of the summary judgment motion.

114. As demonstrated in the appendix, the effects of the motion for summary judgment on expected values of the case and the settlement zone will vary across the spectrum of the recoverability/nonrecoverability of summary judgment costs that would have been incurred at trial. For illustrative purposes we have chosen a midpoint of half-recoverable, half-nonrecoverable. This is consistent with the burden on the nonmovant to reduce the entire record to written form in a manner that imposes substantial independent costs. See Risinger, supra note 55, at 39-41. 


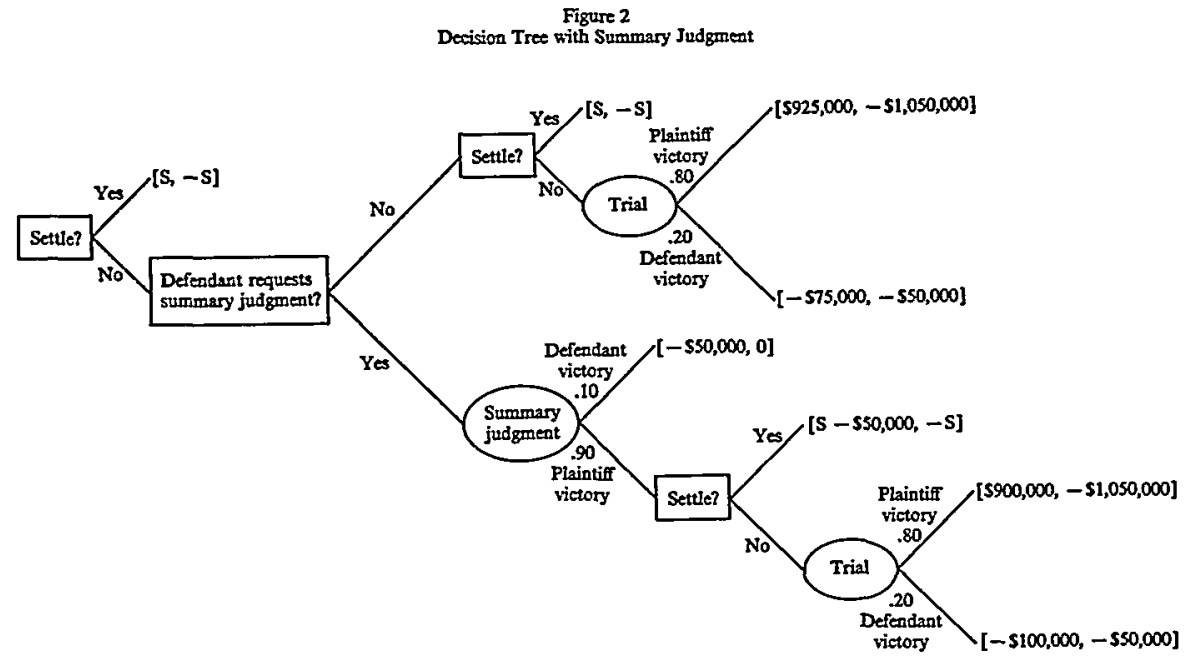

\section{A. Summary Judgment versus No Summary Judgment}

In the absence of a summary judgment procedure, a legal dispute can be conceptualized as a two-stage process consisting of negotiations during the pretrial phase of the case, followed by trial if negotiations fail to result in a settlement. The introduction of summary judgment bifurcates this process into two segments: a first round of negotiations followed by summary judgment, and a second round of negotiations followed by trial. To predict the impact of summary judgment we need to understand the incentives operating on the parties in each of these segments, and to compare them to those that are operative where no summary judgment procedure is available. The incentives for settlement influence the magnitude of the settlement zones-the range of settlements that both parties would prefer over continuing to trial or summary judgment. From settlement zones it is possible to predict when the two parties will settle if they resolve the dispute without going to trial. By examining how different features of the case-award amount, legal expenses, probabilities of prevailing at trial and summary judgment, etc.--influence settlement zones, it is possible to analyze the impact of these variables on the expected outcome of the case. Our goal in this section is to understand how rational economic agents would behave in the presence and absence of summary judgment and to predict how the interactions of such agents will influence the resolution of the case.

We begin by examining a situation in which summary judgment is not an option; we then analyze the diverse effects of introducing a summary judgment option. 


\section{No Summary Judgment}

With no summary judgment, the parties' willingness to settle prior to trial will depend upon the expected value of the claim to each party. These values are defined by the minimum amount the plaintiff would accept in lieu of pressing charges on the one hand, and the maximum amount the defendant would pay on the other; the range of mutually accepted bargains between these amounts is the settlement zone. ${ }^{115}$ These values, delineating the settlement zone, depend on the award to be recovered if the plaintiff prevails, discounted by the probability of prevailing. In our example, assuming that both parties are risk neutral, the one million dollar claim in which the plaintiff has an eighty percent chance of success has an expected value of $\$ 800,000$. From that $\$ 800,000$ figure, we must subtract, for each party, the cost of litigating the claim. Taking account of trial expenses, the plaintiff's expected value of going to trial is $\$ 725,000$ ( $\$ 800,000-\$ 75,000$ ); the defendant's expected loss is $\$ 850,000(-\$ 800,000-\$ 50,000)$. The plaintiff would prefer any settlement that provided a payment greater than $\$ 725,000$ and the defendant would prefer any settlement that provided a payment less than $\$ 850,000$. By definition, the settlement zone is the range between $\$ 725,000$ and $\$ 850,000$. We will adopt the common assumption that parties will settle at the midpoint of the settlement zone-in this case at $\$ 787,500$.

From this example, it is apparent that the value of a claim depends not only on the anticipated recovery but also on the probability of success and the costs to be incurred. To the extent that either a plaintiff's likelihood of success decreases or her costs increase, the expected value of the claim for plaintiff will decrease. Similarly, if plaintiff's likelihood of success decreases and defendant's costs remain constant or decrease, the expected value of the claim against defendant will fall.

\section{Summary Judgment}

The introduction of summary judgment complicates the situation considerably. With summary judgment, the initial value of the claim to both parties depends on: (a) whether the defendant will, in fact, move for summary judgment; (b) the probability that such a summary judgment motion will succeed; and (c) the "recoverability" of plaintiffs' costs (defined as the degree to which plaintiff's costs incurred at the summary judgment stage are recoverable costs that carry over to trial).

115. The economic literature analyzes the likelihood of a particular case going to trial in terms of the "scope" or "range" of settlement values available to the parties. See, e.g., Cooter \& Rubinfeld, Economic Analysis of Legal Disputes and Their Resolution, 27 J. ECON. LIT. 1067, 1075-78 (1989). The early works in this field are Landes, An Economic Analysis of the Courts, 14 J.L. ECON. 61 (1971), Gould, The Economics of Legal Conflicts, 2 J. LEGAL STUD. 279 (1973), and Posner, supra note 11. 
Let us begin by examining the last of these three factors, the impact of which is least obvious. Suppose that the defendant has moved for summary judgment, that the motion has failed, and that both parties are now contemplating settling prior to trial. The plaintiff has already spent $\$ 50,000, \$ 25,000$ of which applies to trial, reducing her trial expenses from $\$ 75,000$ to $\$ 50,000$. The zone of agreement now runs between $\$ 750,000(\$ 800,000-\$ 50,000)$ and $\$ 850,000(\$ 800,000+\$ 50,000)$. The midpoint of the settlement zone is now $\$ 800,000$ instead of $\$ 787,500$. The reason for the shift in the settlement zone is that the plaintiff has less incentive to settle prior to trial as a result of having already invested a substantial portion of her expected trial costs and therefore faces reduced future litigation expenses. It is straightforward to show that the settlement zone will shift upward as the percentage of plaintiff's expenses that are recoverable increases. ${ }^{116}$

When the defendant decides whether to move for summary judgment, two considerations are relevant: the likelihood of prevailing and the increase in the expected value of settlement should the bid fail as a result of the plaintiff's reduced incentive to avoid trial. Consider the example illustrated in Figures 1 and 2. If the defendant fails to move for summary judgment, she is in the situation illustrated in Figure 1 and can expect to settle at the midpoint of the settlement zone: $\$ 787,500$. If she does move for summary judgment, she has a ten percent chance of losing nothing, and a ninety percent chance of losing $\$ 800,000$, the midpoint of the settlement zone after an unsuccessful summary judgment bid, as calculated above. Her expected loss given summary judgment is $\$ 720,000$, well below the expected loss without a summary judgment option. Thus, given the award amount, probabilities of success, and legal expenses in our example, we would expect the defendant to move for summary judgment. The plaintiff's expected gain is equal to $\$ 670,000$, calculated as the likelihood that she prevails at summary judgment times the expected settlement following summary judgment $(.9 \times 800,000)$ minus her legal expenses $(\$ 50,000)$ which are borne regardless of whether summary judgment succeeds or fails. The settlement zone prior to summary judgment, therefore, lies between $\$ 670,000$ and $\$ 720,000$. If the two parties settle prior to summary judgment, we would anticipate a settlement value of $\$ 695,000$, a substantial reduction in defendant's exposure from the baseline of no summary judgment where defendant's expected exposure was $\$ 787,500$.

116. The settlement zone will also shift upward following an unsuccessful summary judgment bid if a failed bid causes the parties to revise upwardly their estimates of the plaintiff's likelihood of prevailing at trial-as with, for example, a resolution of a disputed legal issue at summary judgment. The effect of such a revision, if anticipated by both parties, would be to lower settlement values at the outset, thereby decreasing the wealth transfer from plaintiffs to defendants. The impact of the resolution of legal issues would vary from case to case, depending on the centrality of unresolved standards of liability and whether the case were to be tried by a judge or jury-the resolution of a summary judgment motion being more dispositive in the former case than in the latter. 


\section{B. Consequences of the Availability of Summary Judgment}

The shifting of the settlement zones and the introduction of an additional period of negotiations produced by summary judgment has diverse consequences for the process and outcome of a legal dispute. First, it is likely to alter settlement rates and aggregate legal expenses. By introducing two periods of negotiation, summary judgment might be expected to increase the likelihood of settlement. However, the settlement zone during each of these periods is usually smaller that that prevailing during the single period of negotiation that occurs in the absence of summary judgment. Moreover, failure to resolve the dispute during the first period of negotiations results in expenditures by plaintiff which are generally treated as deadweight losses from a societal perspective. In the first subsection, we attempt to predict whether settlement rates and legal expenses will be greater with or without summary judgment.

Second, as illustrated in the hypothetical by the shift in the initial anticipated settlement point from $\$ 787,500$ to $\$ 695,000$, the introduction of summary judgment results in a wealth transfer from plaintiff to defendant. In the second subsection we explain why this transfer occurs and pinpoint eight features of the case that influence its magnitude.

Third, we will examine the impact of summary judgment on the selective disposal of cases, given that the wealth transfer from plaintiff to defendant will deter initiation of some suits. This subsection focuses on which cases will be discouraged and, in particular, on whether summary judgment has a disproportionately negative impact on non-meritorious "strike suits."

\section{Impact on Settlement}

The premise of the summary judgment trilogy is that a broader use of summary judgment should help alleviate the burdens on the federal courts by allowing pretrial disposition of meritless claims. However, any argument made on behalf of systemic benefits cannot overlook the fact that even without summary judgment only a small percentage of cases actually go to trial. ${ }^{117}$ In effect, the greatest screening mechanism on cases going to trial in the federal judicial system is not any procedural rule at all but the private settlement of disputes by the litigants. Thus, changes that facilitate judicial disposition of cases but impede settlement may fail to relieve, if not exacerbate, court congestion.

117. An extremely small percentage of cases filed in federal courts actually get to trial. McMunigal, The Costs of Settlement: The Impact of Scarcity of Adjudication on Litigating Lawyers, 37 UCLA L. REV. 833, 838 n.15 (1990) (5.3\% of cases filed in federal courts reach trial); Priest, Private Litigants and the Court Congestion Problem, 69 B.U.L. REv. 527, 541 (1989) (roughly 5\% of cases filed reach trial). Studies of particular types of claims often report even greater settlement rates. See H. ROSS, SETTLED OUT OF COURT: THE SOCIAL COST OF INSURANCE CLAIMS ADJUSTMENTS 216 (1970) (95.8\% settlement rate). 
The major incentive for settlement of legal claims is the prospect of expenses associated with litigation. ${ }^{118}$ Given risk neutrality, the settlement zone in a straightforward legal dispute is as broad as the sum of the parties' legal expenses. Therefore, it is natural-as well as customary in the legal and economic literature-to assume that the likelihood of settlement is positively related to the width of the settlement zone. ${ }^{119}$

Let us return once again to our hypothetical. In the absence of summary judgment, the parties began the litigation with a settlement zone of $\$ 125,000$, representing the difference between plaintiff's expected value of $\$ 725,000$ and defendant's expected exposure of $\$ 850,000$, and equal to the sum of the two parties' anticipated litigation expenses. With the introduction of summary judgment, the initial settlement zone is $\$ 50,000$-equal to the plaintiff's anticipated cost of defending against summary judgment. Assuming that the motion for summary judgment is unsuccessful, then the subsequent settlement zone prior to trial is $\$ 100,000$. The narrowing of the settlement zone from the $\$ 125,000$ that would have prevailed if trial were not preceded by summary judgment is caused by the $\$ 25,000$ in plaintiff's costs incurred in defending against summary judgment that are recoverable as anticipated trial expenses. Again this recoverability is critical. If costs are not recoverable at all, the two parties would face a settlement zone equal to $\$ 125,000$. However, if plaintiff's expenses are carried forward $100 \%$, the settlement zone shrinks even further to $\$ 75,000$.

Recall that there are two ways to measure litigation reduction: by the reduction in the proportion of cases that go to trial and by the reduction in the aggregate legal expenses incurred by both parties. The impact of summary judgment on the proportion of cases going to trial depends on whether settlement is more likely to result from a one-stage process of negotiations with a single large settlement zone, or from a two-stage process, each involving a smaller settlement zone. In our hypothetical, without summary judgment, the pretrial settlement zone is equal to $\$ 125,000$. With summary judgment, negotiations are divided into two sessions, the first, prior to summary judgment, with a settlement zone equal to $\$ 50,000$, the second, prior to trial, with a settlement zone of $\$ 100,000$. Intuitively, trial seems less likely in the latter case since the reduction from $\$ 125,000$ to $\$ 100,000$ is small and there is some chance that the parties will settle prior to summary judgment despite the small size of the settlement zone at that point.

118. See Priest, Measuring Legal Change, 3 J.L. EcoN. \& ORG. 193, 197 (1987); cf. Schwab \& Eisenberg, Explaining Constitutional Tort Litigation: The Influence of Attorney Fees Statute and the Government as Defendant, 73 CORNELL L. REV. 719, 742-43 (1988)(applied to constitutional tort litigation).

119. See Coursey \& Stanley, Pretrial Bargaining Behavior Within the Shadow of the Law: Theory and Experimental Evidence, 8 INT'L REV. L. \& ECON. 161, 162-63 (1988) ("Any mechanism that increases the surplus from settlement [the settlement zone] . . . increases the likelihood of settlement."); Cooter \& Rubinfeld, supra note 115, at 1076. 
Of course, the magnitude of the settlement zone following an unsuccessful summary judgment bid depends on the degree to which plaintiff's expenses are recoverable at trial. If such expenses were completely recoverable, resulting in a post-summary judgment settlement zone of $\$ 75,000$, summary judgment will be less likely to result in settlement prior to trial. If plaintiff's expenses were completely non-recoverable, then the post-summary judgment settlement zone will be $\$ 125,000$ and the parties will almost surely be more likely to settle prior to trial than in the absence of summary judgment. ${ }^{120}$

In contrast to the uncertain impact of summary judgment on probability of trial, it seems likely that summary judgment will generally increase litigation costs. First, summary judgment introduces a significant up-front cost to the plaintiff should the two parties fail to reach settlement during the first stage of negotiations-a likely outcome given the small size of the settlement zone at that point. Second, to the extent that plaintiff costs are not recoverable at trial, summary judgment will increase aggregated trial costs. For example, in our hypothetical, aggregate legal expenses for a case going through summary judgment and to trial are $\$ 150,000$, but only $\$ 125,000$ for a case that does not involve summary judgment. ${ }^{121}$

It is impossible to determine whether settlement probabilities or expected litigation expenses are greater or smaller given summary judgment in all cases, without specific knowledge of the size of the settlement zone. Thus, the impact of summary judgment on settlement is ambiguous. However, it appears likely that, in our hypothetical, summary judgment would decrease the aggregate likelihood of going to trial but would increase expected legal expenses. ${ }^{122}$ The latter conclusion follows from the high likelihood that plaintiff and defendant will fail to agree prior to summary judgment, leading to an up-front exposure on the part of the plaintiff.

There is an additional reason to be wary of blanket conclusions concerning the impact of summary judgment on settlement. In a conventional legal dispute

120. We can formalize these intuitions by postulating a function $\mathrm{L}$ (settlement zone) that designates the likelihood that the two parties will settle as a function of the magnitude of the settlement zone. Note that with risk neutrality, the settlement zone is simply the combined expected litigation costs of the parties. Returning to our hypothetical, in the absence of summary judgment, the proportion of cases going to trial will equal $1-L(\$ 125,000)$. With summary judgment, the likelihood of not settling prior to summary judgment will be $1-\mathrm{L}(\$ 50,000)$, the likelihood of avoiding trial through defendant victory at summary judgment is ten percent, and the probability of subsequent settlement is $1-L(\$ 100,000)$. The overall likelihood of trial is $(1-\mathrm{L}(\$ 50,000)) \times .9 \times(1-\mathrm{L}(\$ 100,000))$. While, for the most plausible $\mathrm{L}$ functions, the latter will be smaller than the former, there are a range of convex functions for which the reverse is true.

121. In the absence of summary judgment, the expected value of aggregate litigation costs in our hypothetical is $(1-\mathrm{L}(\$ 125,000)) \times \$ 125,000-$ i.e., the likelihood of not settling times the legal expenses incurred given failure to settle. With summary judgment, the expected value is $\$ 50,000 \times(1-L(\$ 50,000))$ $+\$ 100,000 \times(1-\mathrm{L}(\$ 50,000)) \times .9 \times(1-\mathrm{L}(\$ 100,000))$. For a wide range of plausible $\mathrm{L}$ functions, the latter is likely to exceed the former, in which case aggregate legal costs will be increased by the introduction of summary judgment.

122. This conclusion is based on a comparison of the expressions representing settlement likelihoods and expected costs. See supra notes 120-21. 
without summary judgment both sides simultaneously face strong incentives for settlement. The prospect of litigation costs renders resolution of disputes through litigation a negative sum game for the two parties. Summary judgment, in effect, bifurcates bargaining into two distinct phases, one (prior to summary judgment) in which the plaintiff has a strong desire to settle immediately, and a second (after summary judgment is defeated, but before trial) at which the tables have turned and the defendant disproportionately desires settlement. Recall that in our hypothetical lawsuit, prior to summary judgment, the plaintiff faces the prospect of an immediate payout of $\$ 50,000$ to defend against the anticipated summary judgment motion. Following an unsuccessful summary judgment motion, however, plaintiff has spent a disproportionately greater amount of her anticipated trial costs (because of the recoverability of some summary judgment expenses as trial expenses) while the defendant faces the full brunt of trial preparation. It may be much easier to reach settlement when both sides simultaneously face out-of-pocket costs of not settling. When either side is at a disadvantage relative to the other, the disadvantaged side may not be willing to make the sacrifice logically called for by her weak position. Numerous studies have demonstrated that bargainers are less likely to reach a settlement when inequities of power exist between them than when they are in positions of symmetrical power. ${ }^{123}$

In sum, we find that the likelihood of settlement following an unsuccessful motion for summary judgment is less than the likelihood of settlement prior to trial if summary judgment has not occurred. But the overall impact of summary judgment, taking into account opportunities for settlement prior to summary judgment and prior to trial, is indeterminate. Even taking into account the likelihood that a successful summary judgment motion will terminate some cases, it is not at all clear that the expansion of summary judgment yields the intended consequence of decreasing the likelihood of trial. Furthermore, the expansion of summary judgment will likely increase aggregate legal expenditures, thus producing a corresponding deadweight loss to society. ${ }^{124}$

\section{Wealth Transfer}

Although not an intended consequence of the liberalization of summary judgment, perhaps the most striking and unambiguous impact of the trilogy is a transfer of wealth from plaintiffs to defendants. This is illustrated in our hypothetical by the reduction in the anticipated settlement value from $\$ 787,500$

123. See, e.g., Weg, Rapoport \& Felsenthal, Two-Person Bargaining Behavior in Fixed Discounting Factors Games With Infinite Horizon, in GAMES \& ECON. BEHAVIOR 24-8 (forthcoming 1990); H. RAIFFA, THE ART AND SCIENCE OF NEGOTIATION 51-54 (1982).

124. See Bowles, Economic Aspects of Legal Procedure, in THE ECONOMIC APPROACH TO LAW 191 (P. Burrows \& C. Veljanovski eds. 1981) ("Legal proceedings utilize economic resources that could be used for other purposes."). 
to $\$ 695,000$ with the introduction of the summary judgment option. In the appendix we show that the introduction of summary judgment will never increase, and will often decrease, the value of the suit for plaintiffs and will correspondingly benefit defendants for any award amounts, probabilities, and levels of legal expenditures.

Furthermore, it is instructive to examine the particular features of a case that are likely to increase or decrease the extent of this wealth transfer. The most basic determinant of the size of the wealth transfer is the probability that the defendant will prevail on summary judgment. In the example we have been considering, if the defendant's probability of prevailing were five percent, the settlement zone would run between $\$ 710,000$ and $\$ 760,000$, with a midpoint of $\$ 735,000,{ }^{125}$ substantially greater than the $\$ 695,000$ that would be expected if the probability of defendant success at summary judgment were ten percent. Conversely, if the defendant's probability of prevailing were twenty percent, the settlement zone would range from $\$ 590,000$ to $\$ 640,000$, with a midpoint of $\$ 615,000$.

Additionally, the transfer of wealth depends negatively on the degree to which plaintiff's expenses incurred at summary judgment are recoverable for trial. In our hypothetical, if expenses at summary judgment were completely inapplicable to trial, then the parties would be expected to settle at the outset at $\$ 683,750$, a reduction from the anticipated settlement of $\$ 695,000$ when $\$ 25,000$ of plaintiff's summary judgment expenses were recoverable at trial. ${ }^{126}$ On the other hand, if plaintiff's expenses at summary judgment offset trial expenses dollar for dollar, then the plaintiff would only expend $\$ 25,000$ at trial. The pretrial/post-summary judgment settlement zone would extend from $\$ 775,000$ to $\$ 850,000$ with a midpoint of $\$ 312,500$, and the anticipated settlement point at the outset would be $\$ 706,250$. This represents an increase from the $\$ 695,000$ that would prevail under the baseline assumption of fifty percent recoverability. The settlement zone (and thus anticipated settlements) also will be shifted downward, all else being equal, by an increase in plaintiff's legal expenses at summary judgment or trial, or by a decrease in defendant's anticipated trial expenditures.

125. If the two parties fail to settle prior to summary judgment, they should anticipate settling prior to trial for a payment of $\$ 800,000$ from plaintiff to defendant. However, given a five percent chance that the case will be disposed of at the summary judgment stage, the expected value of the transfer is only $\$ 760,000(.95 \times \$ 800,000)$. The defendant would prefer to pay any amount less than $\$ 760,000$ rather than proceed to summary judgment; the plaintiff, facing legal expenses of $\$ 50,000$ at the summary judgment stage, would rather receive payment greater than $\$ 710,000(\$ 760,000-\$ 50,000)$ than proceed to summary judgment.

126. The $\$ 683,750$ value is derived as follows: Given no recoverability, the zone of agreement at trial would be identical to that given no summary judgment, and the midpoint of the post-summary judgment settlement zone would be $\$ 787,500$. Given summary judgment, there is a ninety percent chance of going to trial, so the expected value at the outset is $\$ 708,750$. However the plaintiff must expend $\$ 50,000$ at summary judgment, so the settlement zone extends from $\$ 658,750$ to $\$ 708,760$ with a midpoint at $\$ 683,750$. 
We have seen how summary judgment emerges from the trilogy as an easy or cost-free procedure for defendants to invoke, and as one that encourages courts to summarily dispose of cases. The liberalized summary judgment standards force additional costs onto plaintiffs at an earlier stage of the litigation and increase the likelihood of summary judgment being granted. These effects of summary judgment under the trilogy trigger the wealth-shifting effects just described.

\section{Selective Disposal of Cases}

The impact of summary judgment is most pronounced for cases that have a high ratio of anticipated costs to anticipated recovery. This is the result of the adverse impact of summary judgment on the expected value of litigation for plaintiffs. As a result, the chilling effect on the initiation of lawsuits is particularly pronounced for marginal or nonmeritorious lawsuits ("strike suits") ${ }^{127}$ in which the expected value of the plaintiff's claim does not cover anticipated legal expenses. It is precisely the "in terrorem" value of such suits that has long concerned the Supreme Court ${ }^{128}$ and has motivated various proposed procedural reforms. ${ }^{129}$

By increasing the anticipated costs, summary judgment discourages a broad - spectrum of plaintiffs from entering the litigation arena. This effect can be seen in three categories of cases: first, cases in which liberal summary judgment will deter the filing of novel legal claims as a result of the low probability of success; second, cases where the higher costs associated with defending against summary judgment will deter filing of well-established legal claims because the anticipated reward is too small to justify suit; and, third, cases where summary judgment will allow defendants to more effectively withstand strike suits. Of these three groups of discouraged cases, only strike suits are a proper target for removal from the judicial system. By definition, these are cases that

127. The concept of strike suits or nuisance suits is well developed in the legal literature and has been used by courts for over forty years. For early references see Koster v. Lumbermens Mutual Co., 330 U.S. 518, 525-26 (1947); id. at 534 (Reed, J., dissenting); Winkelman v. General Motors Corp., 48 F. Supp. 504, 506 (S.D.N.Y. 1942). The Iegal and economic literature has not developed a uniform definition of strike or nuisance suits, although it is generally understood to mean "suit in which the plaintiff is able to obtain a positive settlement from the defendant even though the defendant knows the plaintiff's case is sufficiently weak that he would be unwilling or unlikely actually to pursue his case to trial." Rosenberg \& Shavell, $A$ Model in Which Suits Are Brought for Their Nuisance Value, 5 INT'L REV. L. \& ECON. 3 (1985). We define a strike suit as one in which the expected value to plaintiff is zero or negative as a result of a low probability of success but where the settlement value, defined as the midpoint of the settlement zone, is greater than zero. In such circumstances, the sole incentive for bringing suit is the expectation of a negotiated wealth transfer. We exclude from this category suits intentionally brought to change the positive law or expand the realm of legal rights available to plaintiffs.

128. See Blue Chip Stamps v. Manor Drug Stores, 421 U.S. 723, 740-41 (1975) (even marginal complaint "has a settlement value to the plaintiff out of any proportion to its prospect of success at trial so long as he may prevent the suit from being resolved against him by dismissal or summary judgment").

129. See F. JAMES \& G. HAZARD, CIVIL PROCEDURE, \& 3.11, at 154-55 (3d ed. 1985) ("incidence of the strike suit has led to proposals for tightening the pleading rules"). 
neither expand the realm of positive law nor vindicate pre-existing legal rights. ${ }^{130}$

In effect, strike suits are cases initiated with the intention of extorting a payment from the defendant by threatening a costly legal battle. In such cases, the plaintiff cannot afford to, and thus has no actual intention of, actually going to trial. Summary judgment disproportionately screens strike suits because nonmeritorious cases are unlikely to have a sufficiently developed factual record capable of withstanding summary judgment. Since plaintiffs in such suits are not prepared to commit significant resources to pursuing the litigation, it is also unlikely that they will be able to develop a factual record by extensive use of depositions or other cost-intensive forms of discovery. This effect is compounded by the fact that summary judgment shifts plaintiff's costs forward in time-effectively allowing defendants to force poorly capitalized plaintiffs to incur expenses early in the case while themselves incurring no reciprocal obligation. Forcing such up-front expenditures by plaintiffs further undermines strike suits due to the fact that the monetary judgment to be extracted from the defendant is unlikely to compensate sufficiently for such out-of-pocket costs.

In our hypothetical, the plaintiff's claim is not a strike suit since the expected value of plaintiff's claim exceeds anticipated legal expenses. Suppose, however, that instead of an eighty percent chance of the plaintiff prevailing at trial, there were only a $7.5 \%$ likelihood. Assuming no intent on plaintiff's part to stake out novel legal claims, such a case would qualify as a strike suit since, without summary judgment, the expected value to plaintiff would be zero ( $\$ 1$ million $\times .075-\$ 75,000$ in anticipated litigation expenses). The plaintiff would have no incentive to invest in this litigation, since the expected return is zero. However, since the expected exposure of defendant would be $\$ 125,000$, the settlement zone still stretches between $\$ 0$ and $\$ 125,000$, giving a cagey plaintiff incentive to invest minimally in hopes of inducing a settlement within the settlement zone, or, if such a settlement were not forthcoming, quickly abandoning the case. Providing defendant with a weapon that will increase plaintiff's up-front costs eliminates the viability of a strike suit strategy, since plaintiff is unlikely to commit significant resources to the litigation in light of the marginal expected return. Moreover, the additional costs imposed by summary judgment would create a negative expected value for plaintiff, again discouraging this type of litigation. Plaintiff's aggregate costs of going to trial would be $\$ 100,000$ ( $\$ 50,000$ at summary judgment and $\$ 50,000$ at trial), while the expected gain would be $\$ 75,000$.

130. This conclusion follows from the definition we have used for strike suits. Since, as we have established, such cases do not seek to expand the realm of legally recognized rights, do not seek to vindicate pre-existing rights of limited monetary value, and do not have any positive externalities, it is difficult to articulate any social utility for such suits. Accordingly, the benefits of liberal summary judgment should be greatest here insofar as this procedure allows for an expeditious weeding out of cases whose adjudication would contribute little to the expansion or delineation of legal rights. 
Thus, the temporal shift in plaintiff's costs and the diminished expected value of plaintiff's claims will make strike suits increasingly unviable and facilitate their expeditious removal from the dockets. However, summary judgment under the trilogy remains a powerful but blunt instrument; ${ }^{131}$ while it will no doubt excise strike suits, liberal summary judgment is not sufficiently finely-honed to distinguish sharply between, on the one hand, genuine strike suits and, on the other, cases of limited monetary value ${ }^{132}$ or cases seeking to establish novel legal claims.

\section{When Will Defendants Move For Summary Judgment?}

We have thus far identified various effects of liberally-applied summary judgment: the dismissal and discouragement of strike suits, the impact on settlement rates, and the shift in value of litigation. These impacts all occur only when the defendant is able to make a credible threat to move for summary judgment at the pre-summary judgment stage. As we shall now see, where there is no basis for the motion, there is no benefit to defendant in moving for summary judgment. We now turn, therefore, to an analysis of when it is in the defendant's interest to move for summary judgment.

To predict when the defendant will move for summary judgment, it is important to understand that summary judgment has a benefit and cost to the defendant. Leaving aside for the moment the litigation-specific strategic benefits that summary judgment may offer, the major benefit of summary judgment to the defendant is the possibility that she will prevail on the motion. The greater the likelihood of such an outcome, the more advantageous is summary judgment and the lesser is the defendant's anticipated settlement at the outset.

The major cost of summary judgment is the shift of the settlement zone and subsequent increase in the anticipated settlement amount if summary judgment should fail. This shift, as we demonstrated earlier, depends in large part on the degree to which plaintiff's expenses incurred in defending against summary judgment are recoverable as avoided trial expenses.

131. In the words of Professor Carrington, "the trilogy has made Rule 56 a more powerful engine than the Civil Rules Committee contemplated when it first commenced re-study of the [summary judgment] rule in 1985." Carrington, supra note 8, at 2093.

132. The relation between litigation potential and settlement cannot be ignored. For cases of limited economic claims, the broad-scale increase in plaintiff's up-front expenditures effectively dooms the prospect of enforcing viable legal claims. As one commentator has expressed, "settlement outcomes reflect in some measure the potential results and costs of litigation .... Power to achieve an attractive settlement may be dependent on having adjudication as a viable alternative." Galanter, The Federal Rules and the Quality of Settlements: A Comment on Rosenberg's, The Federal Rules of Civil Procedure in Action, 137 U. PA. L. REv. 2231, 2234 (1989). See also McEwen \& Maiman, Mediation in Small Claims Court: Achieving Compliance Through Consent, 18 LAW \& Soc'Y REV. 11, 46 (1984) ("[T]he most important cost of rules and procedures that deny the poor and weak access to adjudication may be that the disadvantaged are thus effectively denied the opportunity to settle claims informally."). 
Our hypothetical again provides an illustration. Returning to the original premise, if the defendant's probability of prevailing at summary judgment drops from ten to two percent, and if plaintiff's expenses at summary judgment are one hundred percent recoverable, then the defendant's expected loss after filing for summary judgment would be $\$ 796,250$. This is calculated by discounting the midpoint of the post-summary judgment settlement zone by the probability of defendant winning at summary judgment; this would be $.98 \times 812,500$. Since, in this situation, the defendant's loss is greater given summary judgment than without summary judgment, summary judgment provides no leverage and she can minimize losses by settling at the no-summary judgment value of $\$ 787,500 .^{133}$

What we see, therefore, is that, first, a defendant with a weak case does not benefit from the promiscuous filing of a summary judgment motion. Second, when a large fraction of plaintiff's expenditures on summary judgment are applicable to trial, filing the motion will be relatively less advantageous for the defendant. In the appendix, we demonstrate further that the defendant is more likely to move for summary judgment when the stakes in the litigation are high. The greater the potential exposure, the less significant the marginal cost of the summary judgment and, hence, the marginal loss resulting from an elevated settlement zone in the event summary judgment fails. We also show that the greater defendant's anticipated litigation costs and the smaller the plaintiff's, the more advantageous summary judgment becomes for the defendant. ${ }^{134}$

\section{FURTHER RAMIFICATIONS OF THE SUMMARY JUDGMENT TRILOGY}

In order to identify the most basic consequences of the summary judgment trilogy, our economic analysis made a number of simplifying assumptions. First, we assumed that the legal case is a one-shot affair between plaintiff and defendant so that neither side is concerned with confronting the other again in the future or in establishing a public reputation. Second, we assumed that both parties possessed complete knowledge of the facts of the case, including one another's trial strategies. Third, we assumed that the parties are economically

133. The failed summary judgment motion may also have consequences for both parties' perceptions of plaintiff's probability of success. In our example, plaintiff's initial probability of success was set at eighty percent, reflecting both problems of proof and issues of law that may be resolved against plaintiff. If plaintiff survives summary judgment, problems of proof may still be present for trial, but any issues of law will have been resolved in plaintiff's favor. This in turn may affect the bargaining posture of the plaintiff since the probability of success ratio will reflect the favorable resolution of legal issues in plaintiff's favor. See also supra note 116.

134. This follows from two base line points of analysis. First, the probability of judgment for plaintiff is a function of each side's legal expenditures. See Hause, Indemnity, Settlement, and Litigation, or l'll be Suing You, 18 J. LEGAL STUD. 157 (1989). Second, as a general proposition, the greater the potential gain from litigation, the greater the marginal value of resources devoted to litigation by each party. See Katz, Judicial Decisionmaking and Litigation Expenditure, 8 INT'L REV. L. \& ECON. 127 (1988); see generally, Cooter \& Rubinfeld, supra note 115, at 1073. 
rational in the sense of assessing probabilities efficiently and without bias, as well as in their weighing of the various costs and benefits of different options.

Here, we examine the impact of modifying these assumptions in a realistic manner. First, we consider the problem of repeat litigants-primarily defendants-for whom there is a value in establishing a reputation in cost-intensive litigation practices independent of the cost calculus of any particular piece of litigation. Second, we relax the assumption of complete knowledge. If parties are not aware of one another's trial packages, there may be an independent strategic benefit for defendants to force plaintiffs to reveal their trial package. This is particularly true in light of Justice Rehnquist's cryptic reference in Celotex to the plaintiff's need to "produce all of her evidence." 135 Third, we examine the impact of two psychological phenomena that are likely to influence litigants' behavior: overconfidence and failure to ignore sunk costs.

\section{A. Repeat Litigants}

As we demonstrated above, the summary judgment trilogy, which reduces the movant's burden of production and increases defendant's probability of prevailing, constitutes, in effect, a wealth transfer from plaintiffs to defendants. When we introduce the potential for repeat litigation, this impact is, if anything, amplified.

The problems posed by the repeat-litigant status of defendants points to the basic inadequacy of analyzing litigation incentives from the vantagepoint of an isolated case scenario. So long as both parties to the litigation look solely to the controversy at hand, the incentives for litigation strategies, including costs, will be directed by the amount at stake and the prospects of each side prevailing. ${ }^{136}$ Where, however, one of the parties is motivated by future concerns extrinsic to the immediate lawsuit, that party's litigation effort will grow. ${ }^{137}$ As Posner argued, "[a] rational threatener involved in a sequence of similar legal disputes with different people might carry out a threat to overspend in one dispute in order to establish the credibility of similar threats in the other cases."138

Repeat litigation exacerbates the wealth transfer from plaintiff to defendant if defendants are more likely than plaintiffs to be repeat players in litiga-

135. Celotex, 477 U.S. at 326. See supra note 76.

136. This point is made by Professors Cooter \& Rubinfeld: "If both parties are only interested in winning the stakes in this trial, rather than being interested in the law or reputation or future disputes, then the levels of effort chosen and trial outcomes will depend on the relative productivities of both parties." Cooter \& Rubinfeld, supra note 115 , at 1073.

137. Cooter and Rubinfeld analyze this problem from the vantagepoint of a Nash game where the parties have an initial fifty percent chance of winning. They conclude that not only will litigation efforts and expenditures grow, but "the probability of winning will increase for the party with a future interest in victory." Id. at 1074.

138. Posner, supra note 11 , at 432 (emphasis in original). 
tion. ${ }^{139}$ Repeat litigants may want to give the impression of being triggerhappy when it comes to summary judgment-or moving even when it makes no sense in the narrowly construed terms of an individual case. Persuaded of a defendant's readiness to move for summary judgment, plaintiffs may be dissuaded from filing suit by the prospect of high investment levels prior to potential recovery. ${ }^{140}$ Summary judgment may prove an attractive weapon for such repeat litigants even when the likelihood of obtaining summary judgment is minute.

\section{B. Strategic Benefits of Summary Judgment}

Contrary to our stylized assumption that both parties possess all relevant information at the threshold of a suit's liability stage, the point at which parties typically move for summary judgment, the potential for substantial uncertainty exists, particularly concerning the opponent's trial package. The availability to defendants of cost-free summary judgment encourages strategic use of the device to force plaintiff revelation of her trial strategy. ${ }^{141}$

Advocates of summary judgment present it as one of many procedural mechanisms facilitating information exchange. ${ }^{142}$ However, given the fact that the defendant generally has more relevant factual information than the plaintiff, ${ }^{143}$ this information transfer from plaintiff to defendant is unlikely to aid parties in reaching settlement. ${ }^{144} \mathrm{~A}$ defendant tempted by the strategic benefits

139. See generally Perloff \& Rubinfeld, Settlements in Private Antitrust Litigation, in PRIVATE ANTITRUST LITIGATION (S. Salop \& L. White eds. 1987) (reviewing litigation advantage by large institutional defendants in antitrust suits), at 62-70.

140. As Priest \& Klein argue, in situations involving one repeat player, "the stakes will almost surely differ between the parties, because the alternative costs of their future activities are unlikely to be equal." Priest \& Klein, The Selection of Disputes for Litigation, 13 J. LEGAL STUD. 1, 28 (1984). See also Galanter, Why the "Haves" Come Out Ahead: Speculations on the Limits of Legal Change, 9 L. \& SOC. REV. 95 (1974) (predicting repeat players more likely to prevail in litigation).

141. Similarly it has been argued that "parties have an incentive to conduct discovery proceedings to probe for weaknesses in the opponent's case that the looseness of the federal pleading requirements may enable the opponent to conceal in his pleadings." Posner, supra note 11 , at 427 .

142. See, e.g., id., at 435 (describing summary judgment as one of the "[m]any familiar procedural devices ... . designed, in part at least, to reduce the expense of litigation").

143. The presumption of information relevant to the assessment of liability being in the hands of defendants is central to the liberal procedural rules reflected in notice pleading and broad discovery. See Conley v. Gibson, 355 U.S. 41 (1957) (setting forth requirement that pleading only put defendant on notice of nature of claim); see also Friedenthal, A Divided Supreme Court Adopts Discovery Amendments to the Federal Rules of Civil Procedure, 69 CALIF. L. REv. 806, 818-19 \& n.59 (1981) (liberal discovery a stimulus to expansion of substantive remedies); Marcus, The Revival of Fact Pleading Under the Federal Rules of Civil Procedure, 86 CoLUM. L. REV. 433, 441-42 (1986) (liberal pleading tied into pro-plaintiff substantive law changes).

144. In fact, one might argue that to the extent that revealing information is in the interest of both parties, such information will be revealed by plaintiffs in the course of trying to obtain a favorable settlement. This flows from Professor Shavell's analysis of the incentives for the voluntary production of information by plaintiffs. Shavell, Sharing of Information Prior to Settlement or Litigation, RAND J. ECON. (1989-forthcoming). According to Shavell, voluntary disclosure of information will yield an equilibrium in which plaintiffs who stand to benefit from revealing additional information will do so, while those whose bargaining position will not be benefitted will not provide additional information. It follows that forcing 
of cost-free summary judgment would not be seeking information about the potential sources of liability but about plaintiff's ability to arrange and present that information so as to obtain a tactical advantage at trial. The only new information likely to emerge under this scenario is a free peek at the plaintiff's trial tactics. Summary judgment under Celotex provides a unidirectional rule allowing defendants to force plaintiffs to reveal trial strategies while not forcing reciprocal disclosure by defendants. Given the value of this information, ${ }^{145}$ strategic misuse of summary judgment must be considered a real possibility. ${ }^{146}$

\section{Overconfidence}

Although we assumed in our economic analysis that both sides drew similar conclusions about the relevant probabilities from the available evidence, more probably litigants will be "mutually optimistic" about their chances of prevailing at trial. Mutual optimism can explain the failure of parties to settle out of court, ${ }^{147}$ as Posner speculates, ${ }^{148}$ and, in fact, much evidence supports this claim. ${ }^{149}$ For example, parties in arbitrated conflicts tend to overestimate their

all plaintiffs as a class to reveal more information than they otherwise would diminishes the bargaining position of plaintiffs and benefits defendants as a class.

145. "Each party has an incentive to withhold information at the settlement negotiation, knowing that if negotiations fail, the information will be more valuable at trial if the opponent has had no opportunity to prepare a rebuttal to it." R. POSNER, supra note 33, at 526.

146. It therefore comes as no surprise to find among the growing legion of Rule 11 sanctions cases awards for the misuse of summary judgment. See, e.g., Deere \& Co. v. Deutsche Lufthansa Aktiengesellschaft, 855 F.2d 385, 392-93 (7th Cir. 1988) (affirming order that defendant pay plaintiff reasonable attorneys' fees spent opposing summary judgment motion on an issue previously foreclosed).

147. Since litigation is a negative-sum proposition for the parties, meaning that their aggregate wealth will be lessened by litigation, one wonders why litigation should occur with the frequency and intensity that it does. The issue, therefore, is to explain why parties will litigate their disputes rather than settling. Some authors believe that lawsuits occur because some parties will naturally overestimate their chances of winning. Priest \& Klein, The Selection of Disputes for Litigation, 13 J. LEGAL STUD. 1 (1984). One study has shown that it is possible to approximate actual litigation rates by examining the likelihood that optimists who overvalue their relative legal positions will collide. Thus, under reasonable assumptions, the Priest \& Klein model can approximate the litigation rates that actually occur. Silver, Do We Know Enough About Legal Norms, in THE LOGIC OF Soctal ChANGE (D. Braybrooke, ed.) (forthcoming 1991). For further discussion of the literature attributing litigation to optimism, see Gould, The Economics of Legal Conflicts, 2 J. LEgAL STUD. 279 (1973); Landes \& Posner, Adjudication as a Private Good, 8 J. LEGAL STUD. 235 (1979); Shavell, Suit, Settlement, and Trial: A Theoretical Analysis Under Alternative Methods for the Allocation of Legal Costs, 11 J. LEGAL STUD. 55 (1982).

148. The contraposition of "mutual optimism" with "mutual pessimism" is taken from Posner, supra note 11, at 423. The potential reduction in mutual pessimism is attributed to the generation of "information about the opponent's case that causes a party to become more optimistic." Id. Nonetheless, Posner discounts any impact that this phenomenon might have on settlement rates.

149. For a comprehensive overview of the literature on overconfidence, see JUDGMENT UNDER UNCERTAINTY: HEURISTICS AND BIASES 287-355 (D. Kahneman, P. Slovic \& A. Tversky, eds. 1982). Overconfidence may result, in part, from the tendency of parties to assess fairness in a biased manner that favors themselves. For a discussion of fairness biases, see Messick \& Cook, Psychological and Sociological Perspectives on Distributive Justice: Convergent, Divergent, and Parallel Lines, in EQUTTY THEORY: PSYCHOLOGICAL AND SOCIOLOGICAL PERSPECTIVES (D. Messick \& K. Cook, eds. 1983). 
own likelihood of prevailing. ${ }^{150}$ In both arbitration and litigation a last resort decisionmaker gives the parties a strong external referent. Despite the presence of a final resolution by an outside agent, overconfidence by the disputants diminishes the settlement zone, pushing both parties towards trial and, commensurately, preventing settlement.

The common wisdom maintains that increasing the information available to parties will cause their probability estimates to converge. As Posner expressed,

a full exchange of the information in the possession of the parties is likely to facilitate settlement by enabling each party to form a more accurate, and generally therefore a more convergent, estimate of the likely outcome of the case $\ldots . .^{151}$

Convergence of beliefs upon receipt of common information should reduce the "mutual optimism" identified as a principal source of litigation and, concomitantly, as a primary obstacle to settlement. ${ }^{152}$

However, there is good reason to question the assumption that added information leads to convergence of subjective beliefs. Several studies have found exactly the opposite effect; namely, new information received by two parties with polarized views can further exacerbate the discrepancy between them. For example, in one study ${ }^{153}$ subjects who were in favor of or opposed to capital punishment were asked to provide assessments of the deterrent effect of the death penalty. Not surprisingly, these estimates differed substantially for the two groups. Proponents and opponents were then both given the same two academic journal articles to read. One found evidence of a deterrent effect of capital punishment, the other of which reached the opposite conclusion. As a result of exposure to these articles, instead of converging in their beliefs, both groups moved further toward extremes. Each group found the methodology of the study that supported its preexisting belief to be more convincing and tended to view the conflicting research as flawed. ${ }^{154}$

Other research with ramifications for litigant behavior concerns the disparity between increases in confidence as compared with accuracy as people receive

150. See Farber \& Bazerman, Divergent Expectations As a Cause of Disagreement in Bargaining: Evidence from a Comparison of Arbitration Schemes, 104 Q. J. ECON. 99 (1989); Bazerman \& Neale, Improving Negotiation Effectiveness Under Final Offer Arbitration: The Role of Selection and Training, 67 J. APP. PSYCHOLOGY 543 (1982).

151. R. POSNER, supra note 33 , at 525.

152. Posner, supra note 11 , at $422-26$.

153. Lord, Lepper \& Ross, Biased Assimilation and Attitude Polarization: The Effect of Prior Theories on Subsequently Considered Evidence, 37 J. PERSONALITY \& SOC. PSYCHOLOGY 2098-2110 (1979).

154. Biased interpretation of evidence has also been observed in competitive negotiations. Parties tend to interpret the facts in a dispute in a biased manner that favors themselves. The magnitude of the two parties' "egocentric" biases is a strong predictor of failure to settle disputes and of joint losses where failure to settle is costly. See Thompson \& Loewenstein, Egocentric Interpretations of Fairness and Interpersonal Conflict, _ ORG. BEHAV. \& HUMAN DECISION PROCESSES (forthcoming, 1990). 
increasing amounts of information. In one study conducted by Oskamp, psychiatrists were given successively increasing amounts of information about patients. ${ }^{155}$ Oskamp found that, as they received more information, psychiatric clinicians grew increasingly confident about their diagnoses and that their confidence continued to increase long after their actual judgmental accuracy had reached a plateau.

When applied to litigation, these findings challenge the conventional wisdom that more information mitigates mutual optimism and increases willingness to settle. Instead, it appears, new information has the potential to exacerbate overconfidence, particularly when parties are polarized to begin with. To the extent that summary judgment leads to sharing of information, therefore, its impact on settlement is by no means obvious.

\section{Failure to Ignore Sunk Costs}

The so-called "sunk cost" fallacy is a second psychological phenomenon with ramifications for summary judgment. Although economists exhort decisionmakers to ignore sunk costs and to attend only to the prospective benefits and costs of alternative courses of action, few attain this ideal. Instead, individuals often incur further losses ("throw good money after bad") or take great risks in order to recover those losses. The tendency for investors to hold losing stocks, even at the expense of substantial tax benefits, or the tendency for labor disputes to "escalate" after both sides have borne losses from a strike, are both commonly cited illustrations of the failure to ignore sunk costs. ${ }^{156}$

The sunk cost fallacy has consequences for summary judgment because summary judgment is likely to increase the up-front expenditures of the nonmovant. Recall that the settlement zone prior to summary judgment is relatively small ( $\$ 50,000$ in our hypothetical). Given our assumption that settlement probability is positively related to the size of the settlement zone, agreement is relatively unlikely at this stage. At the next stage, where defendant and plaintiff face additional expenditures at trial, the settlement zone should be larger and settlement commensurately likely.

The sunk cost effect, however, may counteract, to some degree, the increase in settlement likelihood that would otherwise occur following an unsuccessful bid for summary judgment. Once the plaintiff has expended resources defending against summary judgment, she may seek to recoup that expenditure by increasing demands during pretrial negotiations. Note that when summary judgment expenses are recoverable, some acceleration of demands is warranted from a

155. Oskamp, Overconfidence in Case-Study Judgments, 29 J. CONSULTING PsYCHOLOGY 261, 261-65 (1965).

156. Staw, The Escalation of Commitment to a Course of Action, 18 ACAD. OF MGMT. REV. 57, 57-61 (1975). See also Shefrin \& Statman, The Disposition to Sell Winners Too Early and Ride Losers Too Long: Theory and Evidence, 40 J. FIN. 777, 777-90 (1985). 
purely economic perspective. The failure to ignore sunk costs will, however, further increase those demands. Acceleration of plaintiff demands above and beyond what is called for by the change in economic incentives will decrease the likelihood of settlement since the defendant does not experience a comparable bias. The sunk cost fallacy, therefore, like the tendency for new information to increase overconfidence, will interfere with settlement.

\section{MOdFICATIONS OF SUMMARY JUdGMENT}

We have shown above that the liberalized summary judgment standards for defendants may have consequences other than those intended. Almost inevitably these summary judgment standards shift wealth from plaintiffs to defendants, and they may not achieve their primary purpose of reducing litigation. Is it possible to devise modifications that avoid these adverse consequences? Here we examine modifications that are intended to discourage the frivolous or strategic misuse of summary judgment by defendants, thus limiting the wealth transfer in their favor. Our proposed modifications rely on the three principle deterrents already established in American law to control litigation abuse: issue preclusion, ${ }^{157}$ fee shifting, ${ }^{158}$ and sanctions. ${ }^{159}$

These modifications seek to discourage unwarranted use of summary judgment as a defendant bargaining tool by deterring its use where the probability of success is low. In light of the problems with the altered summary judgment standards raised above, these modifications also seek to: (a) selectively screen strike suits without compromising the viability of other meritorious suits; (b) decrease or not increase the likelihood that the parties will go to trial; and (c) decrease or not increase the deadweight loss to society resulting from large upfront expenditures.

\section{A. Subsequent Preclusion of Evidence}

One possible modification of summary judgment is to preclude a defendant who moves without substantiation from later introducing any evidence that was available, but not presented in support of the summary judgment motion. ${ }^{160}$ This will raise the up-front cost to the defendant of moving for summary judgment, since defendants who move without incurring the expenditures involved in gathering and presenting evidence will find themselves vulnerable

157. See FED. R. CTV. P. 37(b)(2) which allows for the preclusion of claims or defenses, or the designation of facts that shall be taken as established, as a sanction for discovery abuse.

158. FED. R. CTV. P. 37(b)(2)(E) (providing for the assessment of reasonable expenses, including attorneys' fees, for discovery abuse).

159. FED. R. CIV. P. 11.

160. For a discussion of the use of evidence or issue preclusion, see Louis, Discretion or Law: Appellate Review of Determinations That Rule 11 Has Been Violated or That Nonmutual Issue Preclusion Will Be Imposed Offensively, 68 N.C.L. REV. 733, 753-57 (1990). 
at trial should the plaintiff prevail at summary judgment. This modification eliminates the defendant's ability to wait until learning the outcome of the summary judgment bid before preparing and documenting her case. It forces defendants with marginal summary judgment motions to expend resources in documenting the basis for the summary judgment motion, thereby reducing the likelihood of frivolous use of summary judgment. On the other hand, to the extent that summary judgment discourages strike suits, this modification will weaken this desirable effect by forcing defendants to spend substantial sums up-front in order to take advantage of summary judgment.

Other significant drawbacks to this approach also exist. Forcing the defendant to incur extra expenses in summary judgment proceedings front-loads expenses that in turn lead to greater deadweight losses if the case fails to settle prior to summary judgment but does settle prior to trial. Moreover, the type of expenditures defendants incur at the summary judgment stage will typically be largely recoverable at trial, ${ }^{161}$ so that following a defeat of summary judgment, the defendant's subsequent burden will be reduced and, therefore, her incentive to avoid trial. Forcing the defendant to incur expenses up-front reduces the post-summary judgment settlement zone, which in turn reduces the likelihood of settlement if the two parties fail to settle at the outset and if the plaintiff prevails on summary judgment.

Given that this modification will not necessarily promote settlement, we must consider what its effect will be on overall defendant expenditures. This turns out to be ambiguous. On the one hand, a defendant may spend extensively at the summary judgment stage in order to preserve the ability to fully defend at trial. On the other, the defendant may be disinclined to invest significantly in summary judgment if there is a reasonable prospect of ending the litigation either through settlement or through the actual grant of summary judgment. The relative importance of these two incentive effects cannot be determined without specifying the details (award amount, expenses, etc.) of a particular case.

\section{B. Shifting Fees and Costs}

Another alternative is to provide a defendant with two options: moving without expenditures but immediately reimbursing plaintiff's attorneys' fees and costs should the bid fail (in effect, the English system), or moving with some minimum level of expenditure to avoid the possibility of fee shifting. An obvious problem with this approach is that it adds an additional layer of court inquiry onto determination of the case-specific minimum level of expenditure

161. Typically, the evidence introduced in support of a motion for summary judgment will consist of witness statements reduced to affidavit form, documentary exhibits, and redactions of depositions. Each of these would be presented in some form were the case to reach trial. Accordingly, forcing a defendant to prepare this earlier in the litigation will reduce the defendant's trial costs correspondingly. 
to document credibly the motion for summary judgment. However, courts that have passed on the merits of a summary judgment motion are well-situated to determine whether the motion had substantial support or relied simply on an assertion that no issues of material fact were in dispute.

The use of fee shifting discourages defendants with low probability summary judgment motions from moving for summary judgment. At the same time, this approach still leaves the defendant the option of moving for cost-free summary judgment to ward off strike suits, presumably a high probability motion. Although defendants who may seek to avail themselves of cost-free summary judgment to ward off strike suits still face risks, the consequences would not be as prejudicial to the defendant's case on the merits as would the evidence preclusion alternative discussed previously. In the fee-shifting scenario, a defendant who fails in a cost-free summary judgment motion must absorb the plaintiff's summary judgment costs but remains free to defend fully should the case come to trial. In the issue-preclusion scenario, by contrast, such a defendant would be unable to defend fully by introducing all favorable evidence.

The drawbacks to the use of fee shifting are particular to each of the alternatives available to defendants. If the defendant chooses to move for summary judgment cost-free, the potential for fee shifting reduces the marginal cost to the plaintiff of defending against the summary judgment motion, thereby introducing an incentive for increased expenditures. This in turn will increase up-front expenditures (and thus deadweight losses) by plaintiffs and correspondingly reduce the settlement zone prior to trial to the extent that these expenditures are recoverable. As a result, this modification may reduce the prospects for settlement where defendants move for summary judgment cost-free. ${ }^{162}$

Should the defendant decide to expend resources documenting the summary judgment motion, there is no fee shifting, the plaintiff's marginal costs are unchanged, and plaintiffs have no incentive for excess expenditure on summary judgment. However, the defendant's up-front expenditures will rise, as under the previous modification, with two consequences. First, raising up-front expenditures increases expected litigation costs and reduces efficiency. Second, to the extent that defendant's expenditures are recoverable at trial, the pretrial settlement zone will shrink, consequently reducing the likelihood of settlement.

162. This finding is consistent with the legal and economic literature analyzing the different incentives for settlement and trial under the British and American rules. The prevalent view is that settlement is less likely where costs are shifted. See Katz, Measuring the Demand for Litigation: Is the English Rule Really Cheaper?, 3 J.L. \& ECON. ORG. 143 (1987); Brauetigam, Owen \& Panzar, An Economic Analysis of Alternative Fee Shifting Systems, 17 J.L. \& CONTEMP. PROBS. 173 (1984); Shavell, supra note 144. Professors Cooter and Rubinfeld claim that the British system tends "to increase the frequency of trials by giving more weight to the parties' optimism, and to increase the frequency of trial by making them more costly and more risky." Cooter \& Rubinfeld, supra note 115, at 1078. But see Coursey \& Stanley, supra note 119 (finding some experimental evidence to the contrary). 


\section{Sanctions}

A third alternative is to punish the defendant who moves for summary judgment cost-free and fails by sanctioning the conduct. This modification will discourage the frivolous use of summary judgment. Defendants will be reluctant to file cost-free given the threat of sanctions unless their probability of prevailing is high. They will not want to incur costs at the summary judgment stage unless such costs are likely to yield a return in the form of a disposal of the case at summary judgment. This solution is different from the former in that instead of reimbursing the plaintiff for expenses incurred in a failed summary judgment bid, the defendant incurs a sanction aimed solely at deterring such conduct. Because this sanction is independent of the plaintiff's expenditures, the marginal cost of plaintiff's expenditures on summary judgment is unchanged and plaintiffs should spend the same amount defending against summary judgment that they would have in the absence of this modification. Thus, sanctions avoid the incentive for plaintiff overspending produced by fee shifting.

Other consequences of this modification depend on whether the defendant selects the cost-free option (at the risk of sanctions) or expends the minimum amount necessary to avoid sanctions should the bid for summary judgment fail. If the defendant chooses to file for summary judgment cost-free, the prospect of sanctions should not alter plaintiff's expenditures on defense against the summary judgment motion or the trial expenditures of either party. Therefore, given that the defendant files cost-free, sanctions will have no impact on settlement rates or efficiency. If the defendant moves and prophylactically incurs the minimum level of expenses necessary to avoid sanctions, this modification will decrease economic efficiency by increasing the up-front expenditures by the defendant and, to the extent that defendant's costs at summary judgment are recoverable at trial, decreasing the settlement zone and the likelihood of settling prior to trial. Since these drawbacks are shared with fee shifting, and since sanctions eliminate the incentive for plaintiff overspending, the latter appears to dominate the former in terms of desirability.

\section{Deterring Frivolous Summary Judgment Motions}

In seeking to find a modification of cost-free summary judgment that will alleviate some of the identified problems with the trilogy standard, two points must be kept in mind. First, any modification should preserve the pressing motivation for summary adjudication: the desire to rid the dockets of socially unjustifiable strike suits. Second, the modification should avoid diminution of the settlement zone between the parties and the untoward consequences of such diminution on docket pressures on the courts. 
Given the balance in favor of santions over fee shifting in the prior discussion, the two main contenders for a modification of summary judgment are evidence preclusion and sanctions. Both reduce the desirability of summary judgment for the defendant, which will reduce usage of the procedure, thereby mitigating, to some degree, the straightforward wealth transfer from plaintiffs to defendants.

Both procedures weaken summary judgment as a weapon against strike suits by reducing the desirability of summary judgment to defendants. But evidence preclusion appears to be especially problematical in terms of potentially interfering with the disposition of the case on the merits at trial. Accordingly, evidence preclusion may discourage too broad a sweep of summary adjudication, as opposed to providing a disincentive for its frivolous use. With evidence preclusion, a defendant faced with even a patently marginal suit may be reluctant to file faced with the threat that even a flukish failed summary judgment bid may result in severe consequences at trial. The prospect of sanctions is unlikely to create so sweeping a disincentive as to negate the benefits of quick disposition of frivolous litigation.

The potential impact of these modifications on settlement rates also appears to favor sanctions over evidence preclusion. The potential negative consequences for defense at trial under evidence preclusion is likely to induce defendants to front-load expenses which, in turn, will curtail defendant's anticipated trial expenses and corresponding incentive to settle. Evidence preclusion also frontloads expenses to a greater extent than sanctions, so that deadweight losses will generally be greater under evidence preclusion if the case settles prior to trial but after summary judgment.

In sum, the use of sanctions appears to be the most effective mechanism to deter the frivolous use of summary judgment. However, reliance on sanctions to perform this function requires judges to view the use of summary judgment as a more complicated procedure rather than as a simple expedient with the potential to clear dockets. Courts must be cognizant of the potential for strategic misuse of summary judgment and the resultant wealth transfer to defendants, negative effects on settlement rates, increased litigation expenses, and acrossthe-board deadweight losses for society.

\section{CONCLUSION}

The Supreme Court's 1986 trilogy fundamentally recasts the law governing summary judgment. There can be little doubt that litigants will take notice of the Supreme Court's implicit invitation to file Rule 56 motions as part of its announcement of the new summary judgment structure. Certainly, lower federal courts have received the message and have begun routinely to grant such motions. In light of the limited burden placed upon the moving party and the significant burden on the nonmovant of documenting each point of material fact 
that remains in dispute, summary judgment motions will move closer to the center of the litigation landscape once the bar absorbs the ramifications of the Celotex standard. ${ }^{163}$ This trend will accelerate should the proposed modifications to the federal rules further encourage the use of summary adjudication.

The summary judgment rules restructure the value of legal claims by reallocating the costs and risks associated with litigation, each to the benefit of defendants. Because of the tremendous disparity in both expenditure and risk involved in the filing of a summary judgment motion, defendant-movants face the unmistakable strategic temptation to abuse these motions. In one of the classic introductions to the economic consequences of rules of procedure, for example, Posner acknowledges the possibility that pretrial discovery might engender predatory conduct in litigation: "A litigant could impose heavy costs on an opponent, at very little cost to himself, by demanding information in an amount and form very costly for the other party to supply." 164 While this prospect was once discounted as being "rare," 165 there is little reason to believe that such a sanguine view toward the future is warranted.

163. Greenberg v. Puerto Rico Maritime Shipping Auth., 835 F.2d 932, 934 (1st Cir. 1987) (recent caselaw has invited greater use of Rule 56).

164. Posner, supra note 11, at 433. Dean Friedenthal makes this point post-Celotex: "If one party could, merely by filing an unsupported motion, force an opponent to make a substantial showing, there would be a strong incentive to make such a filing, if for no other reason than to harass the other party and raise its costs of litigation." Friedenthal, supra note 20, at 776. See also Celotex, 477 U.S. at 332 (Brennan, J., dissenting) (allowing movant merely to assert absence of evidence "would simply permit summary judgment procedure to be converted into a tool for harassment").

165. Posner, supra note 11 , at 433 . 


\section{APPENDIX}

\section{THE INCENTIVES FOR SUMMARY JUdGMENT MOTIONS}

The predicted economic consequences of summary judgment under the trilogy can be derived from formal ecomonic models. Table 1 indicates the definitions of variables used in the analysis.

Table 1

Definition of Variables

$c_{\mathrm{P}}^{\mathrm{n}} \quad$ plaintiff expenditures on trial with no summary judgment

$c_{\mathrm{P}}^{s} \quad$ plaintiff expenditures defending against summary judgment

$c_{P}^{t} \quad$ plaintiff expenditures on trial following summary judgment

$c_{D}^{n} \quad$ defendant expenditures on trial with no summary judgment

$c_{D}^{s}$ defendant expenditures incurred on summary judgment

$c_{D}^{t}$ defendant expenditures on trial following summary judgment

$\beta \quad$ fraction of expenses on summary judgment recoverable at trial

A award amount

$\mathrm{q}\left(\mathrm{c}_{\mathrm{P}}^{\mathrm{s}}, \mathrm{C}_{\mathrm{D}}^{\mathrm{s}}, \gamma\right)$ probability of plaintiff victory at summary judgment $(\gamma$ reflects the intrinsic merit of the case at the summary judgment stage)

$\mathrm{p}\left(\mathrm{c}_{\mathrm{p}}^{\mathrm{n}}, \mathrm{c}_{\mathrm{D}}^{\mathrm{n}}, \alpha\right)$ probability of plaintiff victory at trial ( $\alpha$ reflects the intrinsic merit or of the case at the trial stage ${ }^{1}$ )

$\mathrm{p}\left(\mathrm{C}_{\mathrm{P}}^{\mathrm{t}}, \mathrm{c}_{\mathrm{D}}^{\mathrm{t}}, \alpha\right)$

The impact of the expanded availability of summary judgment can be explained by reference to decision tree models showing the incentives presented

1. The introduction of separate parameters, $\alpha$ and $\gamma$, allows for the possibility that there may not be a perfect correspondence between the strength of a plaintiff's case at summary judgment and at trial. 
to each party. Figure A1 displays a simple schematic of the decisions facing plaintiff and defendant in the absence of the summary judgment option.

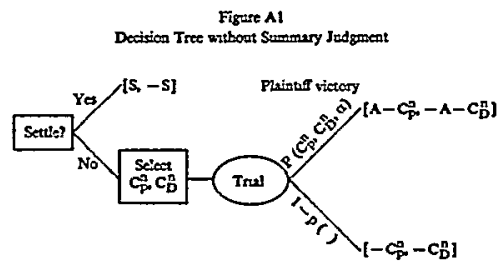

Without summary judgment, the two parties initially face the option of settling out of court. If they fail to reach a mutually acceptable settlement then the case continues to trial. Prior to trial both parties must decide what level of costs $\left(\mathrm{C}_{\mathrm{P}}^{\mathrm{n}}, \mathrm{C}_{\mathrm{D}}^{\mathrm{n}}\right)$ to incur in presenting their case. It is natural to assume that both parties' chances of victory depend positively on the expenses they incur: $\partial \mathrm{p}\left(c_{\mathrm{P}}^{\mathrm{n}}, \mathrm{c}_{\mathrm{D}}^{\mathrm{n}}, \alpha\right) / \partial \mathrm{c}_{\mathrm{p}}^{\mathrm{n}}>0$, and $\partial \mathrm{p}\left(\mathrm{c}_{\mathrm{P}}^{\mathrm{n}}, \mathrm{c}_{\mathrm{D}}^{\mathrm{n}}, \alpha\right) / \partial \mathrm{c}_{\mathrm{D}}^{\mathrm{n}}<0$, and that there are diminishing returns to such expenditures: $\partial^{2} \mathrm{p}\left(\mathrm{c}_{\mathrm{P}}^{\mathrm{n}}, \mathrm{c}_{\mathrm{D}}^{\mathrm{n}}, \alpha\right) / \partial \mathrm{c}_{\mathrm{P}}^{\mathrm{n} 2}<0$ and $\partial^{2} \mathrm{p}\left(\mathrm{c}_{\mathrm{P}}^{\mathrm{n}}, \mathrm{c}_{\mathrm{D}}^{\mathrm{n}}, \alpha\right) / \partial \mathrm{c}_{\mathrm{D}}^{\mathrm{n} 2}>0$.

If pretrial negotiations between the parties were to fail then both would need to decide what level of expenses to incur. The plaintiff selects $c_{P}^{n}$ to maximize her expected value,

$$
E_{\mathrm{p}}=\mathrm{p}\left(c_{\mathrm{P}}^{\mathrm{n}}, c_{\mathrm{D}}^{\mathrm{n}}, \alpha\right) \mathrm{A}-\mathrm{c}_{\mathrm{P}}^{\mathrm{n}} .
$$

The defendant selects $c_{D}^{n}$ to minimize

$$
E_{D}=p\left(c_{P}^{n}, c_{D}^{n}, \alpha\right) A+c_{D}^{n} .
$$

The optimal expenditure levels for each party are such that there is no marginal benefit to either party from increased expenditures. In other words, neither side will find it advantageous to depart from these levels of expenditure. This can be expressed as a Nash equilibrium solution where $\bar{C}_{P}^{n}$ and $\bar{c}_{D}^{n}$ represent the optimal value of each party's costs, such that:

$$
\partial \mathrm{p}\left(\overline{\mathrm{c}}_{\mathrm{P}}^{\mathrm{n}}, \overline{\mathrm{c}}_{\mathrm{D}}^{\mathrm{n}}, \alpha\right) / \partial \mathrm{c}_{\mathrm{P}}^{\mathrm{n}}=-\partial \mathrm{p}\left(\overline{\mathrm{c}}_{\mathrm{P}}^{\mathrm{n}}, \overline{\mathrm{c}}_{\mathrm{D}}^{\mathrm{n}}, \alpha\right) / \partial c_{\mathrm{D}}^{\mathrm{n}}=1 / \mathrm{A}
$$

Note that (A3), together with diminishing marginal returns to expenses, implies that both $\bar{c}_{P}^{n}$, and $\bar{c}_{D}^{n}$ are increasing in $A$; parties will increase their expenditures as the magnitude of the award increases. 
If we assume risk neutrality, ${ }^{2}$ then the minimum amount the plaintiff would be willing to accept in lieu of going to trial is indicated by

$$
S_{\mathrm{Pmin}}=\bar{P}\left(\mathrm{~A}-\overline{\mathrm{C}}_{\mathrm{P}}^{\mathrm{n}}\right)+(1-\overline{\mathrm{P}})\left(-\overline{\mathrm{C}}_{\mathrm{P}}^{\mathrm{n}}\right)
$$

where $\mathrm{P}$ is the probability of plaintiff victory given Nash expenditures as defined in (A3). The maximum amount the defendant would pay to avoid trial is:

$$
S_{D \max }=P\left(A+\bar{c}_{D}^{n}\right)+(1-P)\left(\bar{C}_{D}^{n}\right)
$$

producing a settlement range between $\mathrm{PA}-\overline{\mathrm{c}}_{\mathrm{P}}^{\mathrm{n}}$ and $\mathrm{PA}+\overline{\mathrm{c}}_{\mathrm{D}}^{\mathrm{n}}$. If the parties settle at the midpoint of the settlement range then,

$$
\mathrm{S}=\overline{\mathrm{P}} \mathrm{A}+\left(\overline{\mathrm{C}}_{\mathrm{D}}^{\mathrm{n}}-\overline{\mathrm{c}}_{\mathrm{P}}^{\mathrm{n}}\right) / 2
$$

As discussed in the text, a common assumption is that the probability of settlement increases with size of the settlement range, which in this case is simply the sum of the optimal expenditures of each party $\left(\bar{c}_{\bar{D}}^{n}+\bar{c}_{\mathrm{p}}^{n}\right)$. Given this assumption, any factor which increases this sum (such as an increase in the amount in controversy, A), will increase the proportion of parties that settle out of court.

2. The impact of risk aversion could be addressed by introducing utility functions encoding both parties' risk preferences. With this modification equations (A1) and (A2) would become:

$$
\begin{aligned}
& E_{p}=p\left(c_{P}^{n}, c_{D}^{n}, \alpha\right) U\left(A-c_{p}^{n}\right)+\left[1-p\left(c_{p}^{n}, c_{D}^{n}, \alpha\right)\right] U\left(-c_{p}^{n}\right) \\
& E_{D}=p\left(c_{P}^{n}, c_{D}^{n}, \alpha\right) U\left(-A-c_{D}^{p}\right)+\left[1-p\left(c_{p}^{n}, c_{D}^{n}, \alpha\right)\right] U\left(-c_{D}^{n}\right),
\end{aligned}
$$

and equations (A4) and (A5) would be altered as follows:

$$
\begin{aligned}
& U\left(S_{P \min }\right)=P U\left(A-\bar{c}_{p}^{n}\right)+(1-\bar{P}) U\left(-\bar{c}_{P}^{n}\right) \\
& U\left(-S_{D \text { max }}\right)=P U\left(-A-\bar{c}_{D}^{n}\right)+(1-P) U\left(-\bar{c}_{D}^{n}\right) .
\end{aligned}
$$


Figure A2 expands the decision tree to incorporate summary judgment.

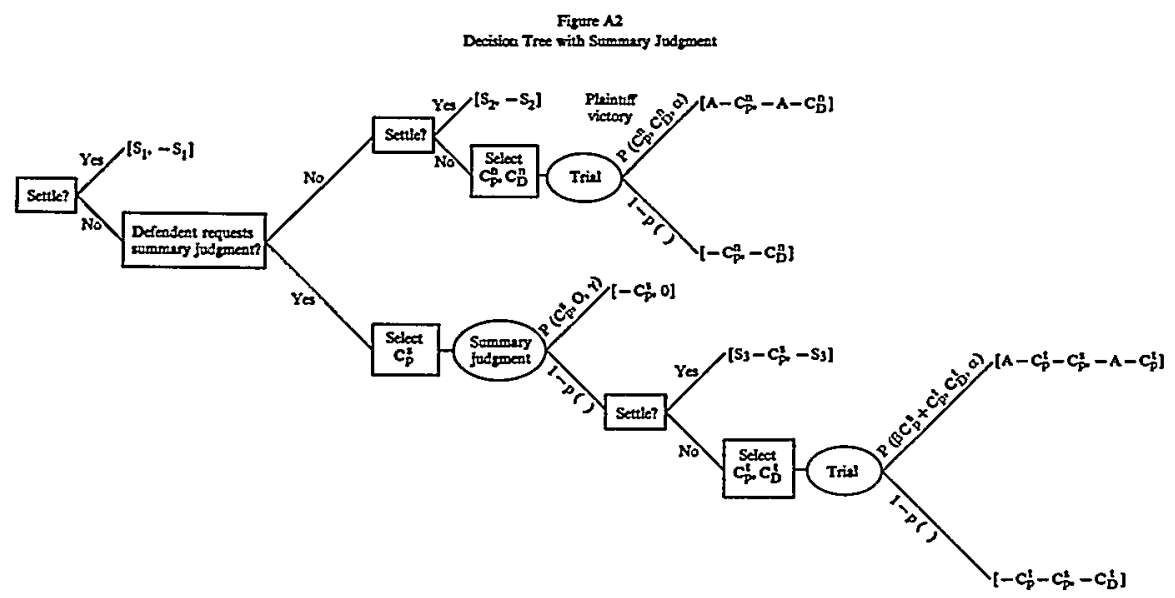

Initially, we assume, both parties have the opportunity to settle on a payment of $S_{1}$ from plaintiff to defendant. If they fail to agree on $S_{1}$, then the defendant has the option to move for summary judgment. If she does not exercise that option (top branch), the parties are in precisely the situation illustrated in Figure $A 1$ and we would anticipate a settlement $S_{2}=S_{1}=\bar{P} A+\left(\bar{c}_{D}^{n}-\bar{C}_{\mathrm{P}}^{n}\right) / 2$. Indeed, if both parties are rational they should anticipate the failure of the defendant to move for summary judgment and should settle for this amount at the outset-i.e., $S_{1}=P A+\left(\bar{C}_{D}^{n}-C_{P}^{n}\right) / 2$.

Will the defendant move for summary judgment? To address this question we must compare her expected loss under summary judgment to her expected loss $\left(\mathrm{S}_{2}\right)$ given no summary judgment.

Assume that the plaintiff would incur costs of $c_{\mathrm{p}}^{s}$ defending against summary judgment, and that it is in the defendant's interest to move without incurring expenditures at this stage. Sufficient conditions for the defendant not to incur expenditures on summary judgment are:

$$
\left.\frac{\partial E_{D}}{\partial c_{D}^{s}}\right|_{c_{D}^{s}=0} \leq 0 \text {, and, } \frac{\partial^{2} E_{D}}{\partial c_{D}^{s 2}} \leq 0 \text { for all } c_{D}^{s} \geq 0,
$$

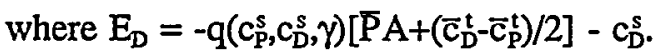


Below it will be shown that

$c_{D}^{t}=c_{D}^{n}-\beta c_{D}^{s}$ and $c_{P}^{t}=c_{P}^{n}-\beta c_{P}^{s}$.

So,

$$
E_{\mathfrak{D}}=-q\left(c_{\mathrm{P}}^{s}, c_{D}^{s}, \gamma\right)\left[\bar{P} A+\left(\bar{c}_{D}^{n}-\beta c_{D}^{s}-\bar{c}_{P}^{n}+\beta c_{P}^{s}\right) / 2\right]-c_{D}^{s}
$$

and,

$$
\left.\frac{\partial \mathrm{E}_{\mathrm{D}}}{\partial \mathrm{c}_{\mathrm{D}}^{\mathrm{s}}}\right|_{\mathrm{C}_{\mathrm{D}}^{\mathrm{s}}=0}=\frac{-\partial \mathrm{q}\left(\mathrm{c}_{\mathrm{P}}^{\mathrm{s}}, \mathrm{c}_{\mathrm{D}}^{\mathrm{s}}, \gamma\right)\left[\overline{\mathrm{P}} \mathrm{A}+\left(\mathrm{c}_{\mathrm{D}}^{\mathrm{t}}-\overline{\mathrm{c}}_{\mathrm{P}}^{\mathrm{f}}\right) / 2\right]}{\partial \mathrm{c}_{\mathrm{D}}^{\mathrm{s}}}+\frac{\beta \mathrm{q}\left(\mathrm{c}_{\mathrm{P}}^{\mathrm{s}}, \mathrm{c}_{\mathrm{D}}^{\mathrm{s}}, \gamma\right)}{2}-1
$$

(A7) will be $\leq 0$ if $-\partial q\left(c_{P}^{s}, c_{D}^{s}, \gamma\right) / \partial c_{D}^{s}$ is sufficiently small, since $\beta q\left(c_{\mathrm{P}}^{s}, c_{D}^{s}, \gamma\right) / 2<1$, always. By differentiating again with respect to $c_{D}^{s}$, it is shown that the second order condition, $\partial^{2} \mathrm{E}_{\mathrm{D}} / \partial \mathrm{c}_{\mathrm{D}}^{\mathrm{s}^{2}} \leq 0$, is also always satisfied.

If the defendant files for summary judgment cost free (as we assume) there are two possible outcomes. First, the defendant can prevail, in which case the plaintiff will lose $c_{p}^{s}$ and the defendant will lose nothing. Alternatively, the summary judgment bid can fail, in which case the two parties have another chance to negotiate a settlement before proceeding to trial. If the case does go to trial, the plaintiff will already have spent $c_{\mathrm{P}}^{s}$ on legal expenses, $\beta c_{\mathrm{P}}^{s}$ of which is recoverable at trial. The probability of plaintiff success depends on plaintiff expenses at trial plus plaintiff expenses at summary judgment that are recoverable at trial, $c_{P}^{t}+\beta c_{p}^{s}$. This sum can be labeled the plaintiff's "effective" expenditure at trial. Since all expenditures that are not recoverable are sunk and irrelevant for future decision making, the optimal level of effective plaintiff expenditures is such that $\beta \overline{\mathrm{c}}_{\mathrm{P}}^{\mathrm{s}}+\overline{\mathrm{c}}_{\mathrm{P}}^{\mathrm{t}}=\overline{\mathrm{c}}_{\mathrm{P}}^{\mathrm{n}}$; effective plaintiff expenditures will equal trial expenditures in the no-summary judgment situation. The same is true for defendant expenditures- $\beta \overline{\mathrm{c}}_{\mathrm{D}}^{\mathrm{s}}+\overline{\mathrm{c}}_{\mathrm{D}}^{\mathrm{t}}=\overline{\mathrm{C}}_{\mathrm{D}}^{\mathrm{n}}$, but, since $\overline{\mathrm{C}}_{\mathrm{D}}^{\mathrm{s}}=0$, by assumption, $\overline{\mathrm{c}}_{\mathrm{D}}^{\mathfrak{t}}=\overline{\mathrm{c}}_{\overline{\mathrm{D}}}^{\mathrm{n}}$. Thus, $\overline{\mathrm{P}}\left(\beta \overline{\mathrm{c}}_{\mathrm{P}}^{\mathrm{s}}+\overline{\mathrm{c}}_{\mathrm{P}}^{\mathrm{t}}, \overline{\mathrm{c}}_{\mathrm{D}}^{\mathrm{t}}, \alpha\right)=\overline{\mathrm{P}}\left(\overline{\mathrm{c}}_{\mathrm{P}}^{\mathrm{n}}, \overline{\mathrm{c}}_{\mathrm{D}}^{\mathrm{n}}, \alpha\right)$. However, $\mathrm{S}_{3}$, the point at which the parties will settle if they settle after an unsuccessful summary judgment bid but before trial, is not identical to $S_{2}$. The reason is that the plaintiff has already spent $\overline{\mathrm{C}}_{\mathrm{P}}^{\mathrm{s}}$ defending herself against summary judgment, and thus the marginal cost for the plaintiff of going to trial after summary judgment is lower than if trial does not follow summary judgment. This lowers the plaintiff's incentive to settle, and her minimum settlement point is raised from $\overline{P A}-\bar{c}_{P}^{n}$ to $\overline{P A}-\bar{c}_{P}^{t}$ which equals $\mathrm{PA}-\overline{\mathrm{C}}_{\mathrm{P}}^{\mathrm{n}}+\beta \overline{\mathrm{c}}_{\mathrm{P}}^{\mathrm{s}}$. The defendant's maximum settlement point remains unchanged from the top branch. ${ }^{3}$ If we assume, again, that the parties settle 
at the midpoint of the settlement range, then $\mathrm{S}_{3}=\overline{\mathrm{P}} \mathrm{A}+\left(\overline{\mathrm{c}}_{\mathrm{D}}^{\mathrm{n}}-\overline{\mathrm{C}}_{\mathrm{P}}^{\mathrm{n}}+\beta \overline{\mathrm{c}}_{\mathrm{p}}^{\mathrm{s}}\right) / 2$. Although the settlement results in a greater payment to the plaintiff, the plaintiff has already incurred costs of $\overrightarrow{\mathrm{c}}_{\mathrm{P}}^{\mathrm{s}}$ at this point so that her actual gain is $\mathrm{S}_{3}-\overline{\mathrm{c}}_{\mathrm{p}}^{\mathrm{s}}$ which is smaller by a factor of $\bar{c}_{p}^{s}(1-\beta / 2)$ than the plaintiff's gain with no summary judgment option. When $\beta$ is zero-when plaintiff expenses on summary judgment are entirely nonrecoverable at trial-then the plaintiff loses the entire amount expended on summary judgment with no redeeming offset. On the other hand, when $\beta$ equals 1 -when plaintiff expenses on summary judgment are entirely recoverable at trial-then, in effect, the cost of defending against summary judgment is split equally between the parties.

The consequences of the additional cost to each party from a failed summary judgment motion are of critical importance. As a result of the reduction in plaintiff trial cost, the settlement zone following a failed summary judgment motion is narrower $-\overline{\mathrm{C}}_{\mathrm{D}}^{\mathrm{n}}+\overline{\mathrm{C}}_{\mathrm{P}}^{\mathrm{n}}-\beta \overline{\mathrm{c}}_{\mathrm{P}}^{\mathrm{s}}-$ than the range of $\overline{\mathrm{C}}_{\mathrm{D}}^{\mathrm{n}}+\overline{\mathrm{C}}_{\mathrm{P}}^{\mathrm{n}}$ that existed prior to the filing of the summary judgment motion. Thus, if the probability of settlement is positively related to the settlement range, the probability of settlement without trial is less likely following an unsuccessful summary judgment bid than in the absence of such a bid.

Finally, to calculate the overall expected values of the suit to both parties, the prospect of additional payment to plaintiff and additional cost to defendant following a defeated motion for summary judgment must be downweighted by the probability, $\mathrm{q}\left(\mathrm{c}_{\mathrm{p}}^{\mathrm{s}}, 0, \gamma\right)$, that the defendant prevails on summary judgment. In other words, the increased settlement value of a claim after a denial of summary judgment must be offset by the likelihood of a grant of summary judgment. To calculate the expected value of plaintiff's claim in light of the altered summary judgment standard, let $\bar{Q}=q\left(\overline{\mathrm{c}}_{\mathrm{p}}^{\mathrm{s}}, 0, \gamma\right)$ be the probability of plaintiff victory on summary judgment given the expected value maximizing value of $\bar{c}_{\mathrm{p} .}^{s}{ }^{4}$ The plaintiff's expected value is

$$
E_{\mathrm{P}}=\overline{\mathrm{Q}}\left[\mathrm{PA}+\left(\overline{\mathrm{C}}_{\mathrm{D}}^{\mathrm{n}}-\overline{\mathrm{C}}_{\mathrm{P}}^{\mathrm{n}}+\beta \overline{\mathrm{C}}_{\mathrm{P}}^{\mathrm{s}}\right) / 2\right]-\overline{\mathrm{C}}_{\mathrm{P}}^{\mathrm{s}},
$$

and the defendant's expected cost is

$$
\mathrm{E}_{\mathrm{D}}=-\mathrm{Q}\left[\mathrm{PA}+\left(\overline{\mathrm{C}}_{\mathrm{D}}^{\mathrm{n}}-\overline{\mathrm{C}}_{\mathrm{P}}^{\mathrm{n}}+\beta \overline{\mathrm{C}}_{\mathrm{P}}^{\mathrm{s}}\right) / 2\right]
$$

would be to increase the value of $p\left(c_{p}^{l}, c_{D}^{l}, \alpha\right)$.

4. $Q$ is calculated by selecting $C_{p}^{s}$ to maximize the expected value to the plaintiff.

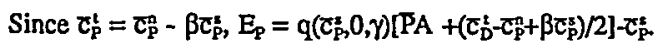

The plaintiff will select the value of $\tau_{p}^{s}$ to maximize the expected value to the plaintiff-i.e., $\partial E_{p} \partial \partial c_{p}^{s}=\partial q\left(c_{p}^{z}, 0, \gamma\right) / \partial c_{p}^{s}\left[\mathrm{PA}+\left(\bar{c}_{D}^{t}-c_{p}^{p}+\beta c_{p}^{s}\right) / 2\right]+\beta q\left(c_{p}^{s}, 0, \alpha\right) / 2-1=0$ 
The defendant will file for summary judgment if her expected loss under summary judgment is less than her expected loss without summary judgment, i.e., if (A9)-(A6) $>0$, or

$$
[1-\bar{Q}]\left[\bar{P} A+\left(\overline{\mathrm{c}}_{\bar{D}}^{\mathrm{n}}-\overline{\mathrm{C}}_{\mathrm{P}}^{\mathrm{n}}\right) / 2\right]>\overline{\mathrm{Q}} \beta \overline{\mathrm{c}}_{\mathrm{P}}^{\mathrm{s}} / 2 \text {. }
$$

This equation identifies the determinants that will lead a defendant to move for summary judgment. For given levels of plaintiff and defendant costs, the defendant's decision to move for summary judgment will be positively related to the award amount $A$ and the intrinsic merit of the case at the trial stage $\alpha$, and negatively related to the intrinsic merit of the case at the summary judgment stage $\gamma$, negatively related to the amount that the plaintiff spends on summary judgment, and negatively related to $\beta$-the degree to which plaintiff expenses on summary judgment are recoverable at trial. In addition, for given probabilities of prevailing on summary judgment and at trial, the defendant is more likely to move for summary judgment as the defendant's expected trial costs increase and as plaintiff's anticipated trial costs decrease. ${ }^{5}$

If it is in the defendant's interest to move for summary judgment, then the parties should settle from the outset at the midpoint of (A8) and (A9)-i.e., at

$$
\mathrm{s}_{1}=\overline{\mathrm{Q}}\left[\overline{\mathrm{P} A}+\left(\overline{\mathrm{C}}_{\mathrm{D}}^{\mathrm{n}}-\overline{\mathrm{C}}_{\mathrm{P}}^{\mathrm{n}}+\beta \overline{\mathrm{C}}_{\mathrm{P}}^{\mathrm{s}}\right) / 2\right]-\overline{\mathrm{C}}_{\mathrm{P}}^{\mathrm{s}} / 2,
$$

which is equal to

$$
\overline{\mathrm{Q}}\left[\overline{\mathrm{P} A}+\left(\overline{\mathrm{c}}_{\mathrm{D}}^{\mathrm{n}}-\overline{\mathrm{C}}_{\mathrm{P}}^{\mathrm{n}}\right) / 2\right]-(1-\overline{\mathrm{Q}} \beta) \overline{\mathrm{c}}_{\mathrm{P}}^{\mathrm{s}} / 2 \text {. }
$$

Comparing A12 to A6, it is evident that the anticipated settlement value is unambiguously lower given summary judgment than without summary judgment. Summary judgment, therefore, always lowers the settlement obtained by the plaintiff if it is in the defendant's interest to file.

5. Higher defendant trial costs increase the defendant's likelihood of moving because they create a disincentive for going to trial. Increasing plaintiff trial costs decreases the likelihood of summary judgment because it has the effect of increasing the defendant's expected gain from trial, decreasing the incentive for summary judgment. 